GEOLOGICAL SURVEY CIRCULAR 805

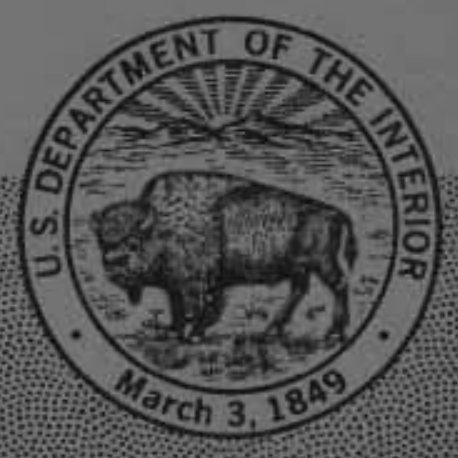

Principal Thorium Resources in the United States

Prepared on behalf of the

U.S. Department of Energy

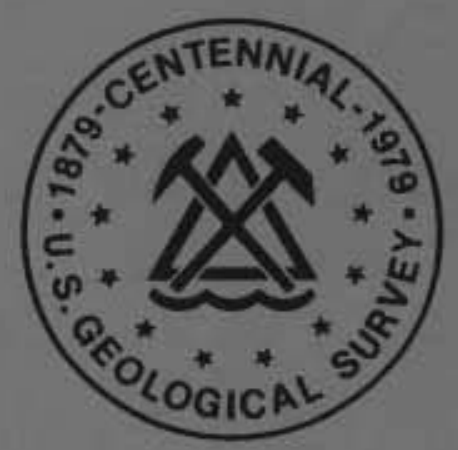




\section{Principal Thorium Resources in the United States}

By M. H. Staatz, T. J. Armbrustmacher, J. C. Olson, I. K. Brownfield, and Maurice R. Brock, U.S. Geological Survey and J. F. Lemons, Jr., L. V. Coppa, and B. V. Clingan, U.S. Bureau of Mines

GEOLOGICAL SURVEY CIRCULAR 805

Prepored on behalf of the

U.S. Department of Energy

Thorium resources are tabulated for the major vein districts, desseminated deposits, massive carbonatite bodies, and the stream placers of North and South Carolina 


\section{United States Department of the Interior}

\section{CECIL. D. ANDRUS, Secretary}

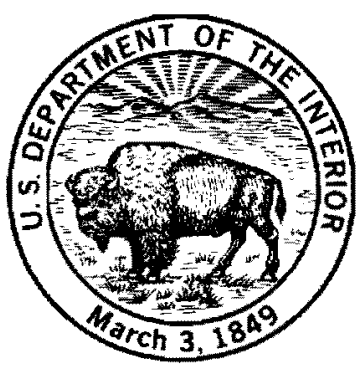

\section{Geological Survey}

H. William Menard, Director 


\section{CONTENTS}

Abstract

Introduction

Summary

Veins -

Lemhi Pass district, Montana-Idaho

Wet Mountains district, Colorado

Powderhorn district, Colorado

Hall Mountain district, Idaho

Diamond Creek district, Idaho

Bear Lodge Mountain district, Wyoming

Mountain Pass district, California
Page

1

2

3

4

9

12

13

15

16

17

19
Page

Disseminated deposits - -

Hicks Dome, Ill. .................................. 21

Bear Lodge Mountains, Wyo. …..................... 23

Powderhorn, Colo. ……. 27

Massive carbonatite bodies …__................................. 27

Iron Hill body, Powderhorn district, Colorado -...... $\quad 29$

Sulphide Queen body, Mountain Pass, Calif. -.....- 31

North and South Carolina placer deposits …............ 33

Beach placer deposits in Florida and Georgia -............ $\quad 39$

References cited -........................ 40

\section{ILLUSTRATIONS}

FIGURE 1. Locations of thorium deposits in the United States

2. Plan of an acid-leach solvent-extraction mill for recovery of thorium and an alternate circuit for recovery of rare earths

3. Geologic and aeroradiometric map of Hicks Dome, Ill.

4. Thorium-content and radiometric map of northern part of the alkalic intrusive core in the Bear Lodge Mountains, Wyo.

5. Relationship of thorium content to total radioactivity in samples from the Bear Lodge Mountains, Wyo.-.-.

6. Generalized geologic map and section of the original surface of the Sulfide Queen carbonatite body --a.-.-.-

7. Known stream-placer areas in North and South Carolina

\section{TABLES}

TABLE 1. ThO ${ }_{z}$ reserves and probable potential resources in short tons of selected types of thorium deposits in the United States

2. $\mathrm{ThO}_{2}$ reserves and probable potential resources in short tons from seven thorium vein districts in the United States

3. $\mathrm{ThO}_{2}$ reserves and probable potential resources in short tons from two massive carbonatite bodies in the United States 


\title{
Principal Thorium Resources in the United States
}

\author{
By Mortimer H. Staatz, Theodore J. Armbrustmacher, Jerry C. Olson, \\ Isabelle K. Brownfield, and Maurice R. Brock, \\ U.S. Geological Survey \\ and \\ Jim F. Lemons, Jr., Luis V. Coppa, and Benjamin V. Clingan, \\ U.S. Bureau of Mines
}

\begin{abstract}
Resources were assessed for thorium in the higher grade and better known deposits in the United States in: (1) veins, (2) massive carbonatites, (3) stream placers of North and South Carolina, and (4) disseminated deposits. Thorium resources for the first three categories were divided into reserves and probable potential resources. Each of these then were separated into the following cost categories: (1) the amount of $\mathrm{ThO}_{2}$ prodicible at less than $\$ 15$ per pound, (2) the amount producible at between $\$ 15$ and $\$ 30$ per pound, and (3) the amount producible at more than $\$ 50$ per pound. The type of mining and milling needed at each deposit determines the capital, operating, and fixed costs of both mining and milling. Costs start with the clearing of land and are carried through to the final product, which for all deposits is $\mathrm{ThO}_{2}$. Capital costs of mining are affected most by the type of mining and the size of the mine. Those of milling are affected most by the kind of mill, its size, and whether or not extra circuits are needed for the separation of rare earths or some other byproduct.

Veins, massive carbonatites, and stream placers of North and South Carolina have reserves of 188,000 short tons of $\mathrm{ThO}_{2}$ and probable potential resources of 505,000 tons of $\mathrm{ThO}_{2}$. Approximately half of the reserves and probable potential resources can be produced at less than $\$ 30$ per pound of $\mathrm{ThO}_{2}$. Veins are the highest grade source in the United States and have total reserves of 142,000 tons of $\mathrm{ThO}_{2}$ and probable potential resources of 343,000 tons. About 90 percent of the reserves and 91 percent of the probable potential resources can be produced at less than $\$ 15$ per pound of $\mathrm{ThO}_{2}$. Seven vein districts were evaluated: (1) Lemhi Pass, Mont.-Idaho, (2) Wet Mountains, Colo., (3) Powderhorn, Colo., (4) Hall Mountain, Idaho, (5) Diamond Creek, Idaho, (6) Bear Lodge Mountains, Wyo. and (7) Mountain Pass, Calif. Eighty-seven

percent of the total reserves and probable potential resources are in the Lemhi Pass and Wet Mountains Districts. The first district has reserves of 68,000 tons of $\mathrm{ThO}_{2}$ and probable potential resources of 124,000 tons that can be produced at less than $\$ 15$ per pound; the second district has 54,000 tons of reserves and 141,000 tons of probable potential resources producible at less than $\$ 15$ per pound. Rare earths are a common byproduct, and in many veins they are from one-half to several times as abundant as thorium.

Massive carbonatite bodies are large-tonnage low-grade deposits. Thorium in these deposits would be a byproduct either of rare earth or of niobium mining. The Iron Hill carbonatite body in the Powderhorn district, Colorado, and the Sulfide Queen carbonatite body in the Mountain Pass district, California, were evaluated. These two deposits contain 40,800 tons of $\mathrm{ThO}_{2}$ in reserves and 125,000 tons of $\mathrm{ThO}_{2}$ in probable potential resources. More than 80 percent of this total is in the Iron Hill carbonatite. This thorium is entirely a byproduct and is producible at less than $\$ 15$ per pound of $\mathrm{ThO}_{2}$. The Sulphide Queen massive carbonatite deposit was being mined in 1977 for rare earths, and thorium could be recovered by adding an extra circuit to the existing mill.

Stream placers in North and South Carolina occur both in the Piedmont and just east of the Fall Line. The reserves of these deposits total 5,270 tons of $\mathrm{ThO}_{2}$, and the probable potential resources are 36,800 tons of $\mathrm{ThO}_{2}$. The Piedmont placers are all too small to produce $\mathrm{ThO}_{2}$ at a cost of less than $\$ 50$ per pound. One placer on Hollow Creek, S.C., just east of the Fall Line had reserves of 2,040 tons of $\mathrm{ThO}_{2}$ that is producible at between $\$ 15$ and $\$ 30$ per pound. Thorium occurs in monazite in these placers. Other heavy minerals that would be recovered with the monazite include rutile, zircon, and ilmenite. In addition to thorium, monazite contains large
\end{abstract}


amounts of rare earths and small amounts of uranium; both can be recovered during the process that separates thorium from the monazite.

Thorium resources in the disseminated deposits are not as well known as those of other types of deposits, and they do not fit into the Department of Energy classification of reserves and probable potential resources. They are categorized here as other resources. Total other resources in three disseminated deposits is $2,460,000$ short tons of $\mathrm{ThO}_{2}$. The three deposits evaluated are (1) a deposit made up of fractured and veined trachyte and phonolite in the Bear Lodge Mountains, Wyo., (2) fine-grained granite in the Powderhorn district, Colorado, and (3) a large erypyovolcanic structure at Hicks Dome, Ill. Any mining would be underground, as most of this deposit occurs at considerable depth. The Bear Lodge Mountains and Powderhorn deposits are exposed at the sur face and could be mined in open pits. Rare earths are much more common than thorium in the Bear Lodge Mountains deposit and probably would be recovered as coproducts in any mining operation.

Another source of thorium from monazite is the Pleistocene beach placers of Florida and Georgia. During 1967 to 1977 these placers were the only source of monazite mined in the United States. They are being mined principally for their titanium minerals, although zircon, garnet, monazite, staurolite, sillimanite, and kyanite are also marketed where present. Monazite makes up only 0.3 to 1.5 percent of the heavy mineral concentrates. Increases in the amount of thorium produced from the beach placers most likely will be due to greater demand for titanium. The amount of $\mathrm{ThO}_{2}$ in monazite recovered from heavy-mineral concentrates that will be produced between 1978 and 1988 is projected at be tween 250 and 350 tons.

\section{INTRODUCTION}

Thorium has been known for a long time to be a potential source material for nuclear reactors; its resources, however, have received little attention. This paper on thorium resources is the first definitive study of these resources in the United States, although some detailed work was done in the early 1950's on the placers of the western Piedomont by the U.S. Geological Survey and the U.S. Bureau of Mines under the auspices of the U.S. Atomic Energy Commission. This resource work was summarized in a paper on the thorium and uranium resources of North and South Carolina Piedmont by Overstreet, Theobald, and Whitlow (1959). The only resource calculations made in a thorium-vein district were done at the Lemhi Pass district, Idaho and Montana, by Sharp and Hetland (1968) in the mid-1960's for the U.S. Atomic Energy Commission. They calculated the thorium resources of this area to be 100,000 tons (short tons) of $\mathrm{ThO}_{2}(1968$, p. 11). This figure, with a few minor additions, has been widely cited as the amount of thorium reserves in the United States (Organization for Economic Cooperation and Development, 1965, p. 20; Sondermeyer, 1975 , p. 173).

United States thorium resources are not confined to one district or even to one type of deposit. Thorium occurs in this country in veins, disseminated deposits, carbonatite bodies, stream placers, beach placers, unconsolidated and consolidated sedimentary rocks, and granitic and alkalic igneous rocks. Grades, quantities, and cost of recovering thorium from these different types of resources vary considerably.

Data on resources used in this report are mainly a byproduct of regional studies of thorium districts made by the U.S. Geological Survey during the past $15 \mathrm{yr}$ (years). Armbrustmacher is responsible for the section on veins in the Wet Mountains and the massive carbonatite body at Iron Hill in the Powderhorn district. Olson put together the sections on veins and fine-grained granite in the Powderhorn district. Brock compiled the data on Hicks Dome. Staatz wrote the other sections either from his notes or from the literature. Brownfield calculated the costs of producing ore from various properties. The costs of different types of mining and milling were calculated by the U.S. Bureau of Mines' team of Lemon, Coppa, and Clingan.

This report does not describe all the thorium deposits in the United States, but it does include most of the higher grade ones, as well as the greater part of the known resources that could be mined relatively cheaply. Specifically, it describes (1) most of the thorium vein districts, including all the larger ones; (2) disseminated deposits, (3) massive carbonatite bodies, and (4) stream placers of North and South Carolina. It also has an estimate of the amount of $\mathrm{ThO}_{2}$ present in the monazite that will be recovered in heavy mineral mining in Florida and Georgia in the next $10 \mathrm{yr}$.

This study was limited by two factors: (1) economic boundaries, and (2) lack of sufficient data on some deposits to evaluate them adequately. Some thorium can be obtained as a byproduct at a very low cost, other thorium is in deposits that are high grade, but some thorium deposits are both low grade and expensive to mine. These latter deposits, which will not be of economic interest for many years, purposely are not covered in this report. They include most thorium-rich ig- 
neous rocks, such as the Conway Granite of New Hampshire, as well as some thorium-rich consolidated sedimentary rocks. The other limiting factor is that sufficient data have not been collected to evaluate certain districts or types of deposits. These unevaluated thorium deposits include (1) stream placers in Idaho, (2) beach placers along the Atlantic coast, (3) unconsolidated sedimentary rocks, (4) ancient Precambrian conglomerate and sandstone, (5) carbonatite dikes, and (6) some of the smaller vein districts. At present these thorium deposits are being studied.

This study was supported by a contract with the U.S. Department of Energy. The terms "reserves" and "probable potential resources" used in this report are those of the Department of Energy and are used so that the thorium resources can be compared more directly with uranium resources. This comparison is important, as both metals compete as fuel sources for nuclear reactors. "Reserves" as used by the Department of Energy, is equivalent, for the most part, to the term "measured and indicated reserves" as used by the U.S. Geological Survey and the U.S. Bureau of Mines, "Probable potential resources" is, likewise, equivalent to "inferred reserves" and some hypothetical resources. Resource figures for veins, massive carbonatites, and stream placers of North and South Carolina are reported two ways. First, the reserves and the probable potential resources of each district are given. Then these figures are divided into cost categories - the amount of each that could be produced for less than $\$ 15 / 1 b$ ( $\$ 15$ per pound) of $\mathrm{ThO}_{2}$, the amount of each that could be produced at cost of between $\$ 15$ and $\$ 30 / \mathrm{lb}$ for $\mathrm{ThO}_{2}$, and the amount of each that could be produced at cost of between $\$ 30$ and $\$ 50 / \mathrm{lb}$ for $\mathrm{ThO}_{2}$. These cost boundaries were chosen so that they would be directly comparable to those used by the Department of Energy in reporting uranium resources.

\section{SUMMARY}

Four types of thorium deposits are discussed in this paper. Three of these, veins, massive carbonatites, and Carolina stream placers have their resources well enough known to be classified as reserves and probable potential resources. These three types of deposits have total reserves and probable potential resources of 693,000 tons of
$\mathrm{ThO}_{2}$. This figure can be divided into 188,000 tons of reserves and 505,000 tons of probable potential resources. If these deposits were only mined for thorium, then 68 percent of the reserves and 62 percent of the probable potential resources are producible at less than $\$ 15 / \mathrm{lb}$ of $\mathrm{ThO}_{2}$. Another 4 percent of the reserves and 3 percent of the probable potential resources are producible between $\$ 15$ and $\$ 30 / \mathrm{lb}$ of $\mathrm{ThO}_{2}$, and 29 percent of the reserves and 6 percent of the probable potential resources are producible at between $\$ 30$ and $\$ 50 / \mathrm{lb}$ of $\mathrm{ThO}_{2}$. The largest amount (70 percent) of the total reserves and probable potential resources is in the veins. The North and South Carolina placers, historically considered a large resource because of their past production, make up only 6 percent of the total reserves and probable potential resources. These placers were mined at the turn of the century principally for the thorium-bearing mineral monazite, using shovels and wooden sluices, but the only modern operation, using a dredge with a connecting mill, was a multiproduct operation in which monazite, rutile, zircon, ilmenite, staurolite, sand, and gravel were recovered (Williams, 1967, p. 25). $\mathrm{ThO}_{2}$ could be produced from this placer at $\$ 30 / \mathrm{lb}$ without the aid of byproducts. Any thorium obtained from massive carbonatite bodies would be as a byproduct either of rare earths or of niobium. Details of the total amount of $\mathrm{ThO}_{2}$ in the four types of deposits are given in table 1. What the table does not show is that many of these deposits have equally valuable coproducts. Vein deposits, in general, have a higher $\mathrm{ThO}_{2}$ content and less byproducts or coproducts than do other types of deposits.

The fourth type is disseminated deposits whose resources are not as well defined as the other three types of deposits. These resources are classified as other resources because present available data do not satisfy the definitional restraints of the formal reserve and probable potential resource categories. This group of resources is estimated to contain 2,200,000 short tons of $\mathrm{ThO}_{2}$. These deposits, which are in general of a lower tenor than the veins, make up the bulk of all the $\mathrm{ThO}_{2}$ resources (70 percent). Some of the disseminated deposits also contain rare earths and niobium. Although the disseminated deposits would not be the first deposits exploited, they would undoubtedly play a major role in any large-scale thorium exploitation. 
TABLE 1,-ThO $\mathrm{O}_{2}$ reserves and probable potential resources in short tons of selected types of thorium deposits in the United States

\begin{tabular}{|c|c|c|c|c|c|c|c|}
\hline \multirow[b]{2}{*}{$\begin{array}{l}\text { Type of } \\
\text { deposit }\end{array}$} & \multirow[b]{2}{*}{$\begin{array}{c}\text { Total probable } \\
\text { potential } \\
\text { resources } \\
\end{array}$} & \multicolumn{2}{|c|}{$\begin{array}{l}\text { Total producible at } \\
\text { less than } \$ 15 / 1 b\end{array}$} & \multicolumn{2}{|c|}{$\begin{array}{l}\text { Total producible at } \\
\text { between } \$ 15 \text { and } \$ 30 / 1 b\end{array}$} & \multicolumn{2}{|c|}{$\begin{array}{l}\text { Total producible at } \\
\text { between } \$ 30 \text { and } \$ 50 / 1 \mathrm{~b}\end{array}$} \\
\hline & & Reserves & $\begin{array}{l}\text { Probable } \\
\text { potential } \\
\text { resources }\end{array}$ & Reserves & $\begin{array}{l}\text { Probable } \\
\text { potential } \\
\text { resources }\end{array}$ & Reserves & $\begin{array}{l}\text { Probable } \\
\text { potential } \\
\text { resources }\end{array}$ \\
\hline $\begin{array}{l}\text { Yeins.............. } \\
\text { Massive } \\
\text { carbonatite }\end{array}$ & 343,000 & 128,000 & 311,000 & 4,610 & 15,100 & 8,000 & 11,500 \\
\hline 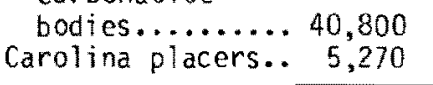 & $\begin{array}{r}125,000 \\
36,800\end{array}$ & $\begin{array}{l}0 \\
0\end{array}$ & $\begin{array}{l}0 \\
0\end{array}$ & $\begin{array}{r}0 \\
2,040\end{array}$ & $\begin{array}{l}0 \\
0\end{array}$ & $\begin{array}{r}9,750 \\
.0\end{array}$ & $\begin{array}{r}9,750 \\
0\end{array}$ \\
\hline Total $\ldots \ldots \ldots \ldots 188,070$ & 504,800 & 128,000 & 311,000 & 6,650 & 15,100 & 157,750 & 21,250 \\
\hline
\end{tabular}

\section{VEINS}

Veins have the largest resource of relatively high-grade thorium in the United States. Most are quartz-feldspar-iron oxide-thorium-bearing veins, which are known from at least 17 widely scattered areas in the United States (fig. 1). These areas are: (1) Lemhi Pass, Mont.-Idaho; (2) Wet Mountains, Colo.; (3) Powderhorn district, Colorado; (4) Hall Mountain, Idaho; (5) Diamond Creek, Idaho, (6) Bear Lodge Mountains, Wyo., (7) Mountain Pass, Calif.; (8) Laughlin Peak; N. Mex; (9) Capitan Mountains, N. Mex.; (10) Gold Hill, N. Mex.; (11) Cottonwood area, Arizona; (12) Quartzsite area, Arizona; (13) Rawhide Mountains, Ariz.; (14) Granite Wash Mountains, Ariz.; (15) Monroe Canyon, Utah, (16) Wausau, Wis.; and (17) Bokan Mountain, Alaska. In some of these districts only one small vein or breccia zone is known, but in some areas many veins are found. In both the Wet Mountains and the Lemhi Pass districts more than 100 veins have been found. Some districts are small-the veins at Hall Mountain are localized in an area of only $0.5 \mathrm{mi}^{2}$ (square mile)-but in some districts, the veins are scattered over a large area. The veins in the Lemhi Pass district are scattered over an area of at least $160 \mathrm{mi}^{2}$ and the veins of the Wet Mountains are scattered over an area of at least $350 \mathrm{mi}^{2}$.

The thorium-bearing veins generally are tabular bodies from several feet to at least 5,000 ft (feet) long (Staatz, 1974, p. 496). Some are narrow lenses. Many veins are more than several hundred feet long and in the Lemhi Pass district, 12 veins are more than $1,000 \mathrm{ft}$ in length. Veins range in thickness from $1 / 64 \mathrm{in}$. (inch) to $50 \mathrm{ft}$. Individual veins commonly are variable in thickness. Although most of the veins are tabular, some are lenticular, and in others, vein material is interstitial to brecciated unmineralized country rock. The mineralogy of the thorium veins generally is similar; quartz or feldspar is the principal gangue mineral, and both commonly are present. Iron oxide veinlets, which are in some places accompanied by manganese oxides, commonly cut the earlier gangue minerals. Thorite is the most common thorium mineral, although in individual veins, monazite, allanite, or brockite may be the principal thorium-bearing mineral. Lesser amounts of barite, calcite, muscovite, biotite, apatite, fluorite, rutile, and pyrite occur in many veins. In addition, minor amounts of many other minerals occur locally in some veins. For example, a total of $\mathbf{4 2}$ minerals have been identified in the veins of the Lemhi Pass district (Staatz, 1972b, p. 60).

This report describes the resources of only the larger and better known vein districts. These are: (1) Lemhi Pass, (2) Wet Mountains, (3) Powderhorn, (4) Hall Mountain, (5) Diamond Creek, (6) Bear Lodge Mountains, and (7) Mountain Pass (fig. 1). The veins in other areas are, in general, small in size and few in number. In a few areas, such as the Bokan Mountain district, Alaska, and Laughlin Peak, N. Mex., insufficient data are available to evaluate them adequately. They are, however, not as large as either the Lemhi Pass or Wet Mountains districts. We feel that the greater part of the known reserves of thorium in veins are described in this paper.

Undiscovered thorium resources in veins are likely to equal those already discovered. Thorium, unlike uranium, has been prospected little during the past $20 \mathrm{yr}$. The lack of economic incentive has 


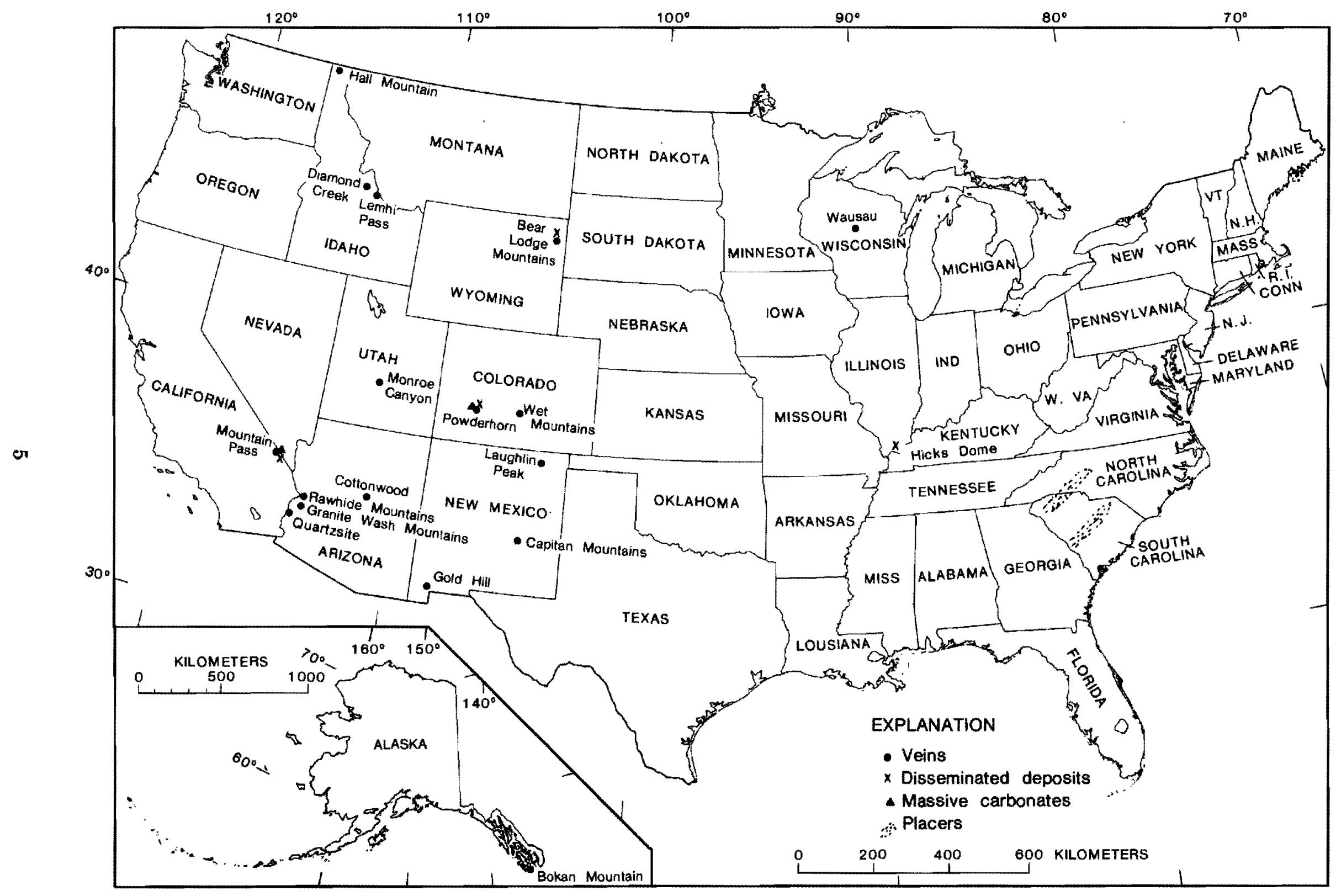

FIoUR E 1.-Location of thorium deposits in the United States. 
hampered exploration on most veins, and only a few have been traced their entire length on the surface or have been explored at depth. Thus, the size of many known deposits is likely to increase as future exploration increases, new deposits will be discovered in the known districts, and new districts will be found.

The thorium resources for each district are reported in two ways: (1) total resources of all the veins, and (2) resources that can be produced at three sets of costs. The first category is divided into reserves and probable potential resources of veins as thin as $0.2 \mathrm{ft}$. Reserves are those resources that are, in part, directly measured and sampled. Reserves in these veins are calculated in the following manner: known length of the vein times average thickness times a depth equal to one-third the length of the vein. The depth of none of the veins, however, is carried to more than $3,000 \mathrm{ft}$. Veins in districts such as the Lemhi Pass and the Powderhorn are exposed over considerable differences in elevation, and this limit appears well warranted. Probable potential resources are extensions of the reserves both laterally and at depth, and they form a block of ore that surrounds the reserves. To identify the probable potential resources, the vein was extended on the surface one-quarter of the known length in each direction. This distance was shortened where rock exposures indicated that the vein either pinched out or had ended by faulting. In a few places, this distance was lengthened where anomalous radioactivity in the soil indicated a continuation of the vein. The same average vein thickness was used as in calculating the reserves. The depth of the probable potential resources block is one and onehalf times the trace of the vein, except that the total depth of reserves plus the probable potential resources is limited to $3,000 \mathrm{ft}$. All veins regardless of length are included in the total resource calculation. If a vein is only exposed in one place, it was assumed to have a length of 50 ft. In a few areas, such as in the Bear Lodge Mountains, the veins are short and tend to pinch out over short distances. Here the length of the vein exposed in only one place is assumed to be 25 $\mathrm{ft}$; these exceptions are noted later under the discussions of each district. Although the resources of even the shortest veins are included in the overall resource calculation, the total amount of resources of all veins having length of less than $200 \mathrm{ft}$ is insignificant when compared to those of the entire district. A tonnage factor of 12 $\mathrm{ft}^{3} /$ short ton (cubic feet per short ton) is used in converting vein volume to vein weight.

The grade of the deposit was obtained by cutting samples across the width of the vein. In a few places, where exposures are poor, grab samples of previously dug-out material were collected. All samples were analyzed for thorium and some, for rare earths and other elements. The average grade of a vein was obtained by adding together the product of the grade of the sample times the length of the sample cut and dividing by the total width of the vein samples cut. In other words, the grade is an average proportioned so that samples taken where the vein is thick were weighted more than those taken where it is thin.

To compare the resources of thorium with those of uranium, the other nuclear fuel, the former are also calculated according to their cost of production. These resources are divided here into reserves and probable potential resources that can be produced at less than $\$ 15 / \mathrm{lb}$ of $\mathrm{ThO}_{2}$, those that can be produced at between $\$ 15$ and $\$ 30 / 1 \mathrm{l}$, and those that can be produced at between $\$ 30 / \mathrm{lb}$ and $\$ 50 / \mathrm{lb}$. To obtain a basis for calculating these costs, a team from the U.S. Bureau of Mines made cost analyses for both mine and mill models. The mine models used for making cost calculations is the cut-and-fill mining system, which was chosen because of its flexibility, grade control, and ground-support advantages. This method, which is designed to use mill tailings as backfill, would fit almost all thorium veins because of their similarity in shape, size, and attitude. Using this method, the veins would be accessed by vertical shafts and connecting drifts. Each deposit would be mined from successive equally spaced levels. After the initial shaft sinking was made to get the vein in production, each shaft would be advanced concurrently with the mining. Along each level, a number of stopes would be made by a series of horizontal cuts above the level. As one cut is completed, mill tailings, consisting of approximately 60 percent solids, would be hydraulically pumped into the space to use as a working platform for further mining as well as for ground support. This mining cycle would be repeated until the level had been completely mined and filled; the next lower level would then be mined. The cut-and-fill system is 
not only an excellent mining method, but because of the lack of surface dumps, there are no downstream silting problems. The ore would be drilled using air-powered jackleg drills and blasted using a breasting round. Slushing equipment and mucking machines would be used to remove the ore from the stopes. The ore would be hauled by rail to the shaft and hoisted to the surface. Cost calculations are based on a 3 - $\mathrm{ft}$ mining width. If the vein is less than $3 \mathrm{ft}$ thick, then the grade of the ore is diluted by the amount of waste necessary to maintain this mining width. Mine recovery of the ore would be assumed to be 90 percent. Although the resources of all veins of more than a certain minimum thickness may be included in total reserve and resource calculations, some properties do not contain enough ore to be economically mined. For purposes of the present calculations, properties containing less than 35,000 tons of minable ore were considered uneconomical and are not included in the resources producible at less than $\$ 15 / \mathrm{lb}$ or between $\$ 15$ and $\$ 30 / \mathrm{lb}$, or $\$ 30$ and $\$ 50 / \mathrm{lb}$ pound.

Mining costs include the cost of mine development, mine plant, mine equipment, and operating costs. Mine-development cost includes surface clearing, roads, initial shaft sinking, drifting, and other preproduction development. Mine-plant cost includes all buildings, hoists, and underground facilities needed during mining. Mine-equipment cost includes all the equipment and supplies needed to bring the property into production. Operating costs are, in turn, divided into direct, indirect, and fixed costs. Direct operating costs are those directly incurred during mining and include labor, supervision, material, utilities, and haulage. The haulage cost is for trucking the ore to the mill and varies with the distance hauled and the amount of ore carried. The indirect operating costs are for administrative and clerical help, plant facility, and general overhead. Fixed operating costs are local taxes and insurance. Fixed costs can be estimated as approximately 3 percent of the capital cost.

Milling costs are much more difficult to calculate than mining costs, as a full-scale mill for recovering thorium from veins has not been built. Data used to obtain milling costs were derived from limited chemical, mineralogical, and metallurigical tests. These analyses indicate that because of the small grain size of the various thorium-bearing minerals and their common inclusion in gangue minerals, different types of physical beneficiation including tabling, size analysis electromagnetic separation, flotation, and electrostatic separation would be ineffective. Thorium, however, can be effectively recovered from these ores by using acid-leach solventextraction techniques. Rare earths, which commonly are as abundant as thorium in these veins, also can be best recovered by leaching and precipitating from solution. The separation of the rare earths adds to the cost, because in order to have a good recovery of rare earths without loss of the thorium, a more concentrated sulfuric acid must be used and an added heating step is necessary. Therefore, if rare earths are to be recovered, the added cost of obtaining the rare earths must be balanced against the value of the rare earths obtained. A mill plan was designed based both on available data from the literature and on discussions with various people who are familiar with thorium and rare earth recoveries. This mill plan has either a thorium circuit or both thorium and rare earth circuits, depending on the cost analysis of the ores for a particular area. A generalized flow sheet showing the principal steps of an acid-leach solvent extraction mill for recovery of thorium with alternate circuits for recovery of rare earths is shown in figure 2.

Milling costs, like mining costs, are divided in to capital and operating costs. Capital costs are for building the mill and buying sufficient equipment to operate it. The principal factors that affect the original costs of the mill are its size and whether or not it has a circuit for recovery of rare earths. One large mill receiving ore from a number of small properties would be less expensive generally than several smaller mills, as the capital cost of one large mill probably will be less than that of the total capital cost of the several smaller mills, and the operating cost of the large mill will be lower due to its larger volume. For the most efficient use of equipment, it is best to plan for a mill life of $15 \mathrm{yr}$ or longer. Mill operating costs can be divided into direct, indirect, and fixed costs. The direct costs include fuel, power, reagent consumption, ball mill consumption, labor, supervision, and supply maintenance. The indirect costs are for administrative and clerical hełp, facility maintenance, and general overhead. Fixed costs are local taxes and insurance. Three 


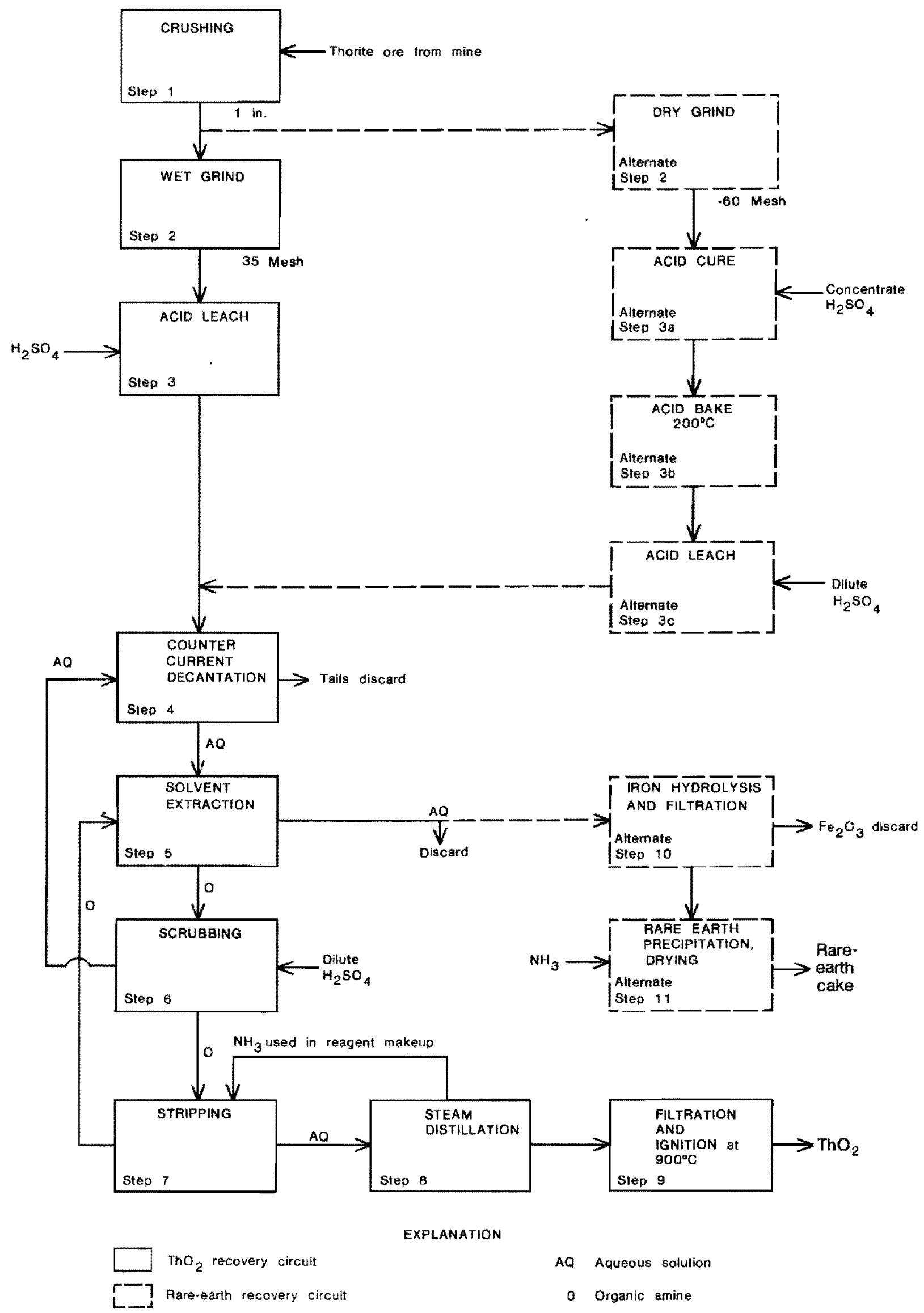

FigurE 2.-Plan of an acid-leach solvent-extraction mill for recovery of thorium and an alternate circuit (dashed lines) for recovery of rare earths. 
variables that most affect the operating cost of the mill are its size, the use of additional reagents and power in a rare-earth circuit, and acid consumption during leaching. Acid consumption is dependent on the composition of the ore leached. If the calcium carbonate content of the ore is greater than 10 percent, the amount of sulfuric acid needed will be sharply increased. If, however, the calcium carbonate content of the ore is less than 10 percent, the acid consumption appears to be related to the iron content.

Calculating the milling cost also involves making several decisions on the size, number, and location of the mill or mills in a particular district. These decisions involve visualization of what will actually occur at a future date and so will vary according to the person making estimates for a particular district; however, they are based both on various economic aspects of the area and on what would be done by a prudent person. Certain economic limitations would be imposed on the size of a mill. An acid-leach solvent-extraction mill design could be built to handle from 100 to 2,000 short tons per day for 350 days a year. In areas where there are many properties, the mill would be a custom mill that would handle ore from all properties up to its capacity. In the Lemhi Pass district, topography is a consideration in selecting mill sites. The Continental Divide separates this district into two parts, and roads over it are steep, crooked, and not usable during the winer months. Hence, mines on either side of the divide would truck ore to mills on their side of the divide. The position of the mill is important in individual mine-cost calculations, as it, in part, determined the cost of trucking the ore from the mine to the mill. Mill sites were chosen in most areas so that they would be close to the largest mine furnishing ore, have a good water supply, and be easily accessible to the principal roads of the district.

The thorium veins in the seven districts discussed in this paper have total reserves and probable potential resources of 485,000 tons of $\mathrm{ThO}_{2}$. Ninety-one percent of this total or 439,000 tons are producible at less than $\$ 15 / \mathrm{lb} ; 4$ percent or 19,700 tons are producible at between $\$ 15 / \mathrm{lb}$ and $\$ 30 / \mathrm{lb}$; and another 4 percent or 19,600 tons are producible at between $\$ 30$ and $\$ 50 / \mathrm{lb}$. The amounts of $\mathrm{ThO}_{2}$ and estimated cost of production for the different districts are shown in table 2.
The Lemhi Pass district lies astride the Continental Divide, which here separates Montana and Idaho. The altitude of this district ranges from 4,700 ft along the Lemhi River on the west side of the district to $9,400 \mathrm{ft}$ on the Continental Divide. The district, which is in the rugged Beaverhead Mountains, is approximately $13.5 \mathrm{mi}$ north-south by $12 \mathrm{mi}$ east-west. A total of 219 thorium veins (Staatz, 1979) are scattered through this large area. The veins occupy shear zones in quartzite and siltite of Precambrian $Y$ age. These rocks resemble the rocks of the Belt Supergroup farther to the north in that they are roughly the same age and their lithology is grossly similar. They differ in being somewhat coarser grained, in lacking calcareous beds, and in having been deposited in a separate basin. Except along the steeper ridges, outcrops are widely scattered. Few thorium veins are exposed. Those which crop out generally have a high quartz content or are on a ridge. Only where a vein consists mainly of quartz will it be more resistant than the surrounding country rock and protrude above it. Thorium-bearing minerals tend to be concentrated in the iron oxide-rich parts of the veins. Thus, parts of the vein that crop out are generally less radioactive than those portions that do not. Many areas that are under thick soil cover have been virtually unexplored. Parts of some veins are exposed at the surface, but the extensions of these veins as well as most other veins are hidden by overburden. Prospecting in this district is commonly done by making a bulldozer trench across a radioactive zone in the soil or across the probable extension of a known vein. Underground workings are not common, although two adits having a total of $1,328 \mathrm{ft}$ of workings were driven on the Last Chance property in Montana, and two adits having $823 \mathrm{ft}$ of workings plus some smaller tunnels are found on the Wonder property in Idaho. Several other properties, including the Shear Zone, Cago No. 12, Buffalo, and Lucky Horseshoe have small adits but none of these exceeds $150 \mathrm{ft}$ in length. Many veins have been only partly explored owing to lack of a market for thorium.

The veins in this area generally occupy small shears parallel to the major structures. Most have a northwesterly strike, although a few have a northeasterly strike. Most have a steep dip, 
TABLE 2.- $-\mathrm{ThO}_{2}$ reserves and probable potential resources in short tons from seven thorium vein districts in the United States

\begin{tabular}{|c|c|c|c|c|c|c|c|}
\hline \multirow[b]{2}{*}{ District } & \multirow[b]{2}{*}{$\begin{array}{l}\text { Total probable } \\
\text { potential } \\
\text { resources }\end{array}$} & \multicolumn{2}{|c|}{$\begin{array}{l}\text { Total producible at } \\
\text { less than } \$ 15 / 1 b\end{array}$} & \multicolumn{2}{|c|}{$\begin{array}{l}\text { Total producible at } \\
\text { between } \$ 15 \text { and } \$ 30 / 1 \mathrm{~b}\end{array}$} & \multicolumn{2}{|c|}{$\begin{array}{c}\text { Total producible at } \\
\text { between } \$ 30 \text { and } \$ 50 / 1 \mathrm{~b}\end{array}$} \\
\hline & & Reserves & $\begin{array}{l}\text { Probable } \\
\text { potential } \\
\text { resources }\end{array}$ & Reserves & $\begin{array}{l}\text { Probable } \\
\text { potent ial } \\
\text { resources }\end{array}$ & Reserves & $\begin{array}{l}\text { Probable } \\
\text { potential } \\
\text { resources }\end{array}$ \\
\hline $\begin{array}{l}\text { Lemhi Pass, } \\
\quad \text { Idaho-Mont.....70,500 }\end{array}$ & 133,000 & 68,000 & 124,000 & 1,650 & 3,330 & 507 & 1,840 \\
\hline $\begin{array}{l}\text { Wet Mountains, } \\
\text { Colo...........64,200 } \\
\text { Powderhorn. }\end{array}$ & 160,500 & 54,000 & 141,000 & 2,540 & 10,100 & 7,280 & 8,880 \\
\hline $\begin{array}{l}\text { Colo............ l,900 } \\
\text { Hall Mountain, }\end{array}$ & 8,500 & 1,300 & 6,700 & 300 & 1,000 & 200 & 700 \\
\hline $\begin{array}{l}\text { Idaho.......... 4,580 } \\
\text { Diamond Creek, }\end{array}$ & 26,300 & 4,540 & 26,100 & 0 & 0 & 0 & 0 \\
\hline $\begin{array}{l}\text { Idaho.......... } 250 \\
\text { Bear Lodge } \\
\text { Mountains, }\end{array}$ & 13,000 & 117 & 12,200 & 115 & 660 & 0 & 0 \\
\hline $\begin{array}{l}\text { Wyo.............. } \\
\text { Mountain Pass, }\end{array}$ & 275 & 0 & 0 & 0 & 0 & 15 & 85 \\
\hline Calif............. & 1,500 & 175 & 685 & 0 & 0 & 0 & 0 \\
\hline Tota1........141,765 & 343,075 & 128,232 & 310,685 & 4,605 & 15,090 & 8,002 & 11,505 \\
\hline
\end{tabular}

with only 15 percent of them dipping less than $40^{\circ}$. The veins range in length from a few feet to at least $4,350 \mathrm{ft}$. The vein of largest continuous known length is the Last Chance in Montana. The Shear Zone vein, also in Montana, has been mapped for $6,000 \mathrm{ft}$ (Staatz, 1972b, pl. 1). It is not a continuous vein but a shear zone along which several closely spaced, branching, and en echelon veins occur. Fifteen veins in the district are more than 1,000 ft long. These veins are the Shear Zone, Last Chance, main vein at the $\mathrm{ThO}_{2}$, Cago No. 12 , central vein at the Iola, north vein of the Silver Queen 52B, Contact, northwest-trending vein on the Black Rock (Montana) property, north vein on the G\&G Nos. 1,2 , and 5 claims, Viola, Lucky Horseshoe, vein on G\&G Nos. 6 and 8 claims, northeast vein on the Reactor, principal vein on the Deer, and southeast vein on the Frying Pan (Staatz, 1979). The first six veins of the above group have each been traced for more than $2,000 \mathrm{ft}$. The thorium veins vary considerably in thickness and range from thin seams to $40 \mathrm{ft}$ thick. Although some veins pinch and swell abruptly, many are fairly uniform for most of their length; changes in thickness are most common near the ends of the vein. The maximum thickness of 63 percent of the veins in the district is $1 \mathrm{ft}$ or greater, and for 6 percent (16 veins) it is more than $10 \mathrm{ft}$.

The thorium veins here are generally brown to reddish brown due to a high iron oxide content.
The grain sizes of the gangue minerals rarely exceed 1/8 in (inch), and those of the thorium minerals are generally between 0.0008 and 0.004 in. In addition, every vein has been granulated by shearing. The basic mineralogy of the veins is fairly simple and consists primarily of quartz or microcline gangue cut by numerous irregular limonite or hematite veinlets and masses that contain thorium minerals and small amounts of various other accessory minerals. Although many minerals occur throughout the veins, only a few of the minerals make up as much as 10 percent of any sample. In addition to quartz, microcline, hematite, and limonite, only calcite and siderite make up this amount of any sample. Calcite is the chief gangue mineral in seven veins; siderite occurs in substantial amount in part of only one. Where these two minerals occur in other places, they make up only minor amounts of the veins. Minerals such as thorite, barite, magnetite, rutile, pyrite, monazite, muscovite, and apatite are found fairly frequently in the samples examined but occur in only minor amounts in each sample.

Thorite is the dominant thorium mineral in the Lemhi Pass veins. Monazite is the next most common thorium-bearing mineral and was found in about one-quarter of the samples examined. Although monazite generally is not as abundant as thorite, in seven veins it is considerably more plentiful. Brockite, a calcium thorium phosphate, 
is present in nine veins. At four of these localities, it is the principal thorium mineral. Other thorium-bearing and rare-earth-bearing minerals occur in only a few veins and generally in minor amounts. Xenotime was noted in four veins; allanite in three; synchysite, a rare-earth calcium fluorocarbonate in two; and bastnaesite, a rareearth fluorocarbonate, and doverite, an yttrium calcium fluorocarbonate, in one each. In addition, 23 other accessory minerals have been found in minor amounts in one or more veins. These minerals include those of copper, lead, zinc, and molybdenum. A detailed description of the mineralogy of the thorium veins may be found in Staatz (1972b, p. 57-74) and Staatz (1979).

The $\mathrm{ThO}_{2}$ content of the thorium veins in the Lemhi Pass district is known from about 420 samples. The values range from 0.0008 to 9.4 percent. The samples represent a wide variety of vein materials. Some represent thin seams in quartzite country rock, but most are entirely of vein material which ranges from almost barren quartz to thorium-rich parts of veins. Although the $\mathrm{ThO}_{2}$ content of individual parts of different veins may vary widely, the grade of large sections of a particular vein may be fairly constant.

The uranium content of 33 of these samples varies from 0.00001 to 0.0355 percent, and the thorium-to-uranium ratios of these samples range from 4.7 to 2,600 . The thorium-to-uranium ratio of most samples, however, falls in the range of 30 to 300 .

The total rare-earth oxide content of these veins is about equal to the $\mathrm{ThO}_{2}$ content. Although rare earths commonly occur in the same minerals as thorium, there is no apparent relationship between the amount of one in a particular vein and the amount of the other. In 80 analyses of the thorium veins, the total rare earth oxide content ranges from 0.042 to 10.95 percent (Staatz, Shaw, and Wahlberg, 1972, p. 76-77, Staatz, 1979; Austin, 1968). Analyses of samples from two properties, the Lucky Horseshoe and the Buffalo, show as much as 4 percent total rareearth oxides. The relative amount of each lanthanide commonly varies from vein to vein. In 31 samples, which were carefully analyzed for the individual lanthanides (Staatz, Shaw, and Wahlberg, 1972), cerium was most abundant in six, neodymium in 17 , gadolinium in three, dysprosium in two, and two lanthanides were equally abundant in three samples. In most veins, however, the cerium group of rare earths (lanthanum, cerium, praesodymium, neodymium, samarium, and europium) make up most of the total rare earths. In at least nine veins, the yttrium group of rare earths, especially yttrium, make up a significant part of the total rare earths.

Reserves and probable potential resources were calculated for all veins that have an average thickness of $0.2 \mathrm{ft}$ or more. By this criterion, resources data were calculated for 114 separate veins. Although most properties contain only a single vein, some have several. There are five closely spaced veins on the Deer, and four each on the Buffalo, Silver Queen 52B, and Reactor properties. The total reserves and resources of the various veins vary widely, and range from as little as 0.7 ton to thousands of tons of $\mathrm{ThO}_{2}$. Total reserves for this district are 70,700 short tons of $\mathrm{ThO}_{2}$; total probable potential resources are 133,000 short tons of $\mathrm{ThO}_{2}$. Together they total 203,700 tons of $\mathrm{ThO}_{2 .}$. The average grade of these veins varies from 0.034 to 3.83 percent $\mathrm{ThO}_{2}$, but 99 percent of these reserves come from veins that have between 0.1 and 2.0 percent $\mathrm{ThO}_{2}$. Although the total resources are the aggregate resources of 114 veins, 95 percent of these resources are in the 10 largest veins. These veins are the Beaverhead; Black Rock (Montana); Cago No. 12; Contact; G\&G Nos. 1, 2, and 5; G\&G nos. 6 and 8; Last Chance; Lucky Horseshoe; Shear Zone; and $\mathrm{ThO}_{2}$ (Staatz, 1979). These 10 veins have an overall average grade of 0.43 percent $\mathrm{ThO}_{2}$.

The Lemhi Pass district also has substantial resources of rare earths. Many deposits, however, have not been analyzed for rare earths. The average total rare earth oxide grade for the 29 veins on which some analytical data are available is 0.51 percent. If this average grade is interpreted to be that of the entire district, then there are approximately 65,500 tons of reserves and 132,000 tons of probable potential resources of total rare earth oxides in the Lemhi Pass district.

Cost calculations were made on all properties containing more than 35,000 tons of vein material in the total reserves and probable potential resources. Thirty-four veins on 30 properties were evaluated. Eighteen of the veins could produce $\mathrm{ThO}_{2}$ at less than $\$ 15 / \mathrm{lb}$, six at between $\$ 15$ and $\$ 30 / \mathrm{lb}$, three at between $\$ 30$ and $\$ 50 / \mathrm{lb}$, and the rest at more than $\$ 50 / \mathrm{lb}$. Ore was assumed to go to one of three hypothetical mills. One mill was to be on the west side of the Continental Divide and 
was to process ore from the Idaho mines; the other two were to be on the east side of the Divide and were to handle mainly ore from the mines in Montana. A total of 192,000 tons of $\mathrm{ThO}_{2}$ is producible in the Lemhi Pass district at less than $\$ 15 / \mathrm{lb}$. This total can be divided into 68,000 tons of $\mathrm{ThO}_{2}$ in reserves and 142,000 tons in probable potential resources. This product would be obtained from $43,000,000$ tons of ore having an average grade of 0.53 percent $\mathrm{ThO}_{2}$. As the grade of the ore decreases, the cost of recovering it increases, and the average grade of ore where $\mathrm{ThO}_{2}$ could be produced at prices between $\$ 30$ and $\$ 50 / \mathrm{lb}$ is 0.13 percent. An equal amount of rare earths occurs in the veins.

\section{WET MOUNTAINS DISTRICT, COLORADO}

Thorium deposits in the Wet Mountains district occur principally west of the Wet Mountains proper in an area referred to as the De Weese Plateau by Scott and Taylor (1975). These deposits are scattered over an area nearly $38 \mathrm{mi}$ long, from north of the Arkansas River south to the Custer-Huerfano County line, by nearly $15 \mathrm{mi}$ wide, from the Wet Mountains Valley on the east to the Wet Mountains. Most of them occur in an area between the WestcliffeTexas Creek faults on the west and the Ilse fault on the east.

The thorium deposits are spacially and genetically related to three alkalic complexes of Cambrian age (Olson and others, 1977), the McClure Mountain Complex that includes the mafic-ultramafic rocks at Iron Mountain (Shawe and Parker, 1967), the Gem Park Complex (Parker and Sharp, 1970), and the complex at Democrat Creek (Heinrich, 1966, p. 339). A variety of younger lamprophyre, carbonatite, and red syenite dikes, and thorium-bearing quartzfeldspar-barite veins intersect the rocks of the alkalic complexes as well as the Precambrian X and $Y$ metasedimentary and igneous country rocks (Scott and others, 1976). Anomalous concentrations of thorium are found in the carbonatite bodies (Armbrustmacher, 1979) and red syenite dikes, and especially in the quartzfeldspar-barite veins, fracture zones, and fenites that envelop these deposits. The veins and fracture zones have the greatest economic potential and are discussed in the following pages.
The fracture zones, which are persistent linear features as much as $8 \mathrm{mi}$ long, generally have a northwesterly strike and typically are 3 to $4 \mathrm{ft}$ thick. These zones commonly cross the foliation of the Precambrian metasedimentary rocks at right angles. Fracturing apparently is better developed across the well-foliated metasedimentary rocks than across the poorly foliated igneous rocks. Most of the fracture zones and veins occur south of the alkalic complexes, which may reflect the greater abundance of well-foliated metasedimentary rocks in that area. Several types of dike and vein material may occur along a given fracture zone, and in a few places various types overlap along some fracture zones, carbonatite dikes may replace earlier lamprophyre or red syenite dikes; along others quartz-feldsparbarite veins intersect carbonatite dikes; or parts of fracture zones may have been invaded by mineralizing fluids without abundant gangue minerals. In a few places, fracturing is later than the dikes and veins.

The veins and fracture zones vary in mineral content, but in many places they contain abundant amounts of smoky quartz and barite. Specular and earthy hematite, goethite, and microcline generally are common; calcite, thorite, and galena occur in variable amounts; and pyrite, chalcopyrite, dolomite, chlorite, siderite, cerussite, xenotime, brockite, sphalerite, rutile, and other minerals are sparse. Light stableisotope studies of minerals in the veins show that physical-chemical conditions for thorite deposition were remarkably uniform throughout the area. The ${ }^{18} \mathrm{O}$ values of quartz range from 9.3 to 12.1 permil and indicate that the hydrothermal fluids had a uniform thermal history throughout the area. The ${ }^{34} \mathrm{~S}$ values for coexisting barite and galena range from 5.1 to 8.1 permil and -14.1 to -24.3 permil, respectively, and suggest that the hydrothermal solutions derived their sulfur from igneous sources and that vein deposition occurred under a rather limited range of $\mathrm{pH}$ and oxygen fugacity conditions.

Exploration of the quartz-feldspar-barite veins and fracture zones consists mainly of shallow prospect pits, many of which no longer expose bedrock. Samples commonly were collected from these pits or from dumps if the amount of radia tion warranted it. Because of the lack of data between pits where the vein or fracture zone is covered, estimates of thorium reserves between 
workings are subject to error and probably tend to be somewhat overestimated. At a few locations, mainly the Beardsley, Pine Tree, Anna Lee, and Hardwick deposits, there are some underground workings, but the workings mostly have caved or filled with water.

A total of 202 samples of veins and fracture zones were analyzed for thorium and uranium by gamma-ray spectrometer and for 31 additional elements by semiquantitative spectrographic analysis. The samples contain an average of 0.46 percent $\mathrm{ThO}_{2}$, ranging from 0.00075 to 10.2 percent. The maximum uranium value of 0.036 percent but samples generally contain less than 0.0005 percent. The average thorium-to-uranium ratio is 64 . The thorium-to-total-rare-earth ratios are somewhat variable but average about 2.2 , with maximum total rare-earth concentrations near 1 percent.

The total $\mathrm{ThO}_{2}$ reserves of the Wet Mountains district are 64,200 tons; in addition, there are 160,500 tons of $\mathrm{ThO}_{2}$ in probable potential resources.

Cost analyses were done on 29 veins and fracture systems whose reserves and probable poten. tial resources total at least 35,000 tons. $\mathrm{ThO}_{2}$ could be produced from 10 of these at a cost of less than $\$ 15 / \mathrm{lb}$, from six of them at a cost of between $\$ 15$ and $\$ 30 / \mathrm{lb}$, from four of them at a cost of between $\$ 30$ and $\$ 50 / \mathrm{lb}$, and the remainder at a cost of greater than $\$ 50 / \mathrm{lb}$. The amount of $\mathrm{ThO}_{2}$ producible at less than $\$ 15 / \mathrm{lb}$ is 195,100 tons, which is divisible into 54,100 tons of $\mathrm{ThO}_{2}$ in reserves and 141,000 tons in probable potential resources. The average grade of the veins containing $\mathrm{ThO}_{2}$ that is producible at less than $\$ 15 / \mathrm{lb}$ is 0.51 percent. The amount of $\mathrm{ThO}_{2}$ producible at between $\$ 15 / \mathrm{lb}$ and $\$ 30 / \mathrm{lb}$ is 12,640 tons, which is divisible into 2,540 tons of reserves and 10,100 tons of probable potential resources. The amount of $\mathrm{ThO}_{2}$ producible at between $\$ 30 / \mathrm{lb}$ and $\$ 50 / \mathrm{lb}$ is 16,160 tons. This amount is divisible into 7,280 tons of reserves and 8,880 tons of probable potential resources. The average grade of the ore producible at between $\$ 30 / \mathrm{lb}$ and $\$ 50 / \mathrm{lb}$ is only 0.11 percent.

\section{POWDERHORN DISTRICT, COLORADO}

The Powderhorn district occupies $250 \mathrm{mi}^{2}$ in southern Gunnison County, Colo. (fig. 1). About
250 veins were prospected for thorium, chiefly during 1950-56. The area is underlain largely by metasedimentary and metavolcanic rocks intruded by Precambrian granitic and other igneous rocks. In late Precambrian or Cambrian time, about 570 million years ago, the Precambrian rocks were intruded by alkalic igneous rocks and carbonatite of the complex at Iron Hill and by slightly younger diabase dikes (Olson and others, 1977). Mesozoic sedimentary rocks and Tertiary volcanic rocks originally covered much of the area, but now are exposed only on scattered mesas and ridges where they cover the older rocks. Thorium deposits in the Powderhorn district have been described by Olson and Wallace (1956) and by Hedlund and Olson (1961). The geology of the district and location of thorium deposits are shown on maps by Olson (1975), Hedlund and Olson (1973, 1975), and Olson and Hedlund (1973). The geology of the alkalic igneous complex at Iron $\mathrm{Hill}$ has been described by Larsen (1942), Temple and Grogan (1965), Rose and Shannon (1960), and Nash (1972).

Abnormal amounts of thorium are found in the following types of deposits in the Powderhorn district: (1) veins, (2) disseminations in several small granite plutons, (3) a large massive carbonatite body, (4) scattered carbonatite dikes, (5) magnetite-perovskite-apatite bodies, and (6) trachyte dikes. Only resources of the first type, veins, are described in this section of the report. The second and third types are described in other sections of this report. The last three types have been discussed briefly by Hedlund and Olson (1961).

Veins contain the highest grade thorium concentrations in the district. They are as much as $3,500 \mathrm{ft}$ in length, but most cannot be traced for more than a few hundred feet. The veins range in thickness from a fraction of an inch to $15 \mathrm{ft}$, but most are less than $2 \mathrm{ft}$ thick. They commonly occur in steeply dipping shear or breccia zones within the Precambrian rocks. In the area 2-5 mi north of the complex at Iron Hill, most of the veins strike slightly north of east, but in the northwestern part of the district they generally strike northwest. The veins cut and generally are discordant to the foliation of the metamorphic and igneous rocks. The type of host rock apparently has little effect on the localization of the veins. 
The thorium veins are composed of thorite, white to smoky quartz, jasper, pink potassium feldspar, calcite, specular and earthy hematite, goethite, magnetite, barite, pyrite, and sporadic synchysite, apatite, purple fluorite, biotite, sodic amphibole, rutile, monazite, vanadinite, bastnaesite and various sulfides. The chief thorium mineral, thorite, is very fine grained and is intergrown with ferric oxides minerals. Carbonate minerals are abundant in some of the veins, commonly replacing silicate minerals, quartz, and barite, and are associated with ferric oxide minerals. Vug fillings of coarsely crystalline calcite occur locally in some veins. Pink and white barite is present in small amounts in many of the thorium veins, and it is a major constituent in a few. Sulfide minerals are present but not abundant in the veins; they include pyrite, chalcopyrite, galena, and minor sphalerite.

Varicolored jasper, mostly yellowish to reddish brown, has replaced much of the carbonate gangue in veins that lie just below the Tertiary volcanic capping. This type of replacement is well developed on Sapinero Mesa in the northwest part of the Powderhorn district. Jasper replacement of the carbonate gangue has been found in veins that lie within $100 \mathrm{ft}$ of this volcanic capping. Locally the jasper forms pseudomorphic replacements of the carbonate and has apparently retained some of the dispersed thorium, as veins partly replaced by jasper show radioactivity in both the jasper and carbonate gangues. The effects of oxidation, leaching, and jasperization might result in some increase or decrease in the original thorium content of near-surface vein material, but without sufficient subsurface data on possible changes in grade, the surface exposures are assumed to be representative of vein grade at depth. The jasperization may have resulted from the action of hydrothermal fluids localized near an ancient Oligocene land surface just beneath the base of the flows.

The $\mathrm{ThO}_{2}$ content of samples from thorium veins ranges from less than 0.01 percent to as much as 4.9 percent. The $\mathrm{ThO}_{2}$ content generally is less than 1 percent, however, and is 0.05 to 0.1 percent in many of the veins examined in this district.

The complex at Iron Hill contains a minor element assemblage characteristic of many alkalic rocks, including titanium, phosphorus, strontium, barium, rare earths, and vanadium. Among these, the niobium and rare earths are sufficiently valuable and widespread in the thorium veins to be considered in discussing the economic potential.

The thorium veins commonly contain anomalous amounts of niobium. Some of it is in columbite, which has been identified in the South Beaver Creek area. The $\mathrm{Nb}_{2} \mathrm{O}_{5}$ content of 46 vein samples that were semiquantitative spectrographically analyzed ranges from 45 to 2,150 ppm (parts per million); overall average is $\mathbf{2 4 5}$ ppm. The $\mathrm{ThO}_{2}$-to- $\mathrm{Nb}_{2} \mathrm{O}_{5}$ ratio in these veins increases generally northwestward from the complex at Iron Hill from 2.6 to 16.7. The average ratio of all samples is 6.8 .

The thorium veins contain an appreciable amount of rare earths, which is generally in excess of the amount of thorium. The amounts of various rare earths was determined by semiquantitative spectrographic analysis. The proportions of total rare earth oxides to $\mathrm{ThO}_{2}$ varies considerably but the average is 2.4 . The ratio of the two is greatest in veins near the south and west sides of the complex at Iron Hill where the total rare-earth oxides are about five times as abundant as the $\mathrm{ThO}_{2}$. The cerium group of rare earths is approximately 2.7 times more abundant than the yttrium group of rare earths; they also vary considerably in proportion to one another from sample to sample. the cerium group rare earths is proportionately greater near the south and west sides of the complex at Iron Hill where the ratio of the cerium group to the yttrium group is approximately 10 to 1 . This ratio is least in an area within $5 \mathrm{mi}$ of the northern side of the complex where most of the veins are somewhat richer in yttrium group rare earths than in cerium group rare earths.

Uranium was determined in 58 vein samples. The amount is generally low and exceeds $10 \mathrm{ppm}$ in only three samples. The highest uranium value is $41 \mathrm{ppm}$. The thorium-to-uranium ratios of these samples are between 1 and 10 in six samples, 10 to 30 in eight samples, 30 to 70 in 20 samples, 70 to 130 in 10 samples, and 130 to more than 1,000 in 14 samples.

Thorium deposits shown on maps of the Powderhorn district (Olson, 1975; Hedlund and Olson, 1973, 1975; Olson and Hedlund, 1973) were examined briefly with a scintillation counter during geologic mapping of the area, and some reserves were estimated. The majority of the 
deposits are small or low in grade; hence, it is only a minority that contribute significantly to the total resources. In 1976 and 1977, J. C. Olson reexamined 67 of the deposits with the aid of a portable four-channel gamma-ray spectrometer and collected an additional 66 samples. The field gamma-ray spectrometer readings were calibrated with the sample analyses from the same stations by a linear regression analysis to provide a rough guide to approximate thorium content for field readings on unsampled veins.

Isorad maps were drawn for several deposits showing contours of equal thorium content. The gamma-ray spectrometer readings, coupled with sample analytical data, provide a reasonable approximation of the thorium content of the surficial layer of the deposit. Inferences regarding the extent and thorium content of the deposit at depth require, in addition, consideration of: (1) the amount of cover that might locally obscure the vein, (2) the dispersal of radioactive elements by slope wash, soil creep, or leaching, and (3) the possible enrichment of surficial material by selective removal of constituents other than thorium. Generally, the surficial thorium content was assumed to be fairly representative of that at depth except where radioactivity may be obscured by ground cover.

Resource estimates were made on a total of 54 veins. The average tenor of 21 veins is between 0.01 and 0.03 percent $\mathrm{ThO}_{2}$, and that of another 10 veins is between 0.03 and 0.05 percent $\mathrm{ThO}_{2}$. Thirteen of the veins estimated have an average tenor greater than 0.1 percent $\mathrm{ThO}_{2}$. Reserves in all 54 veins amount to 1,900 tons of $\mathrm{ThO}_{2}$ of which 1,600 tons is in veins having an average grade greater than 0.1 percent. Probable potential resources total an additional 8,500 tons. The veins in this district having a grade of at least 0.05 percent $\mathrm{ThO}_{2}$, which make up most of the total resources, are widely scattered and occur in secs. $14,15,16$, and 20 , T. 47 N., R. 2 W.; secs. 1 , $2,4,9,10,15$, and 24 , T. 47 N., R. 3 W.; sec. 34 , T. 48 N., R. 3 W.; sec. 10 , T. 46 N., R. 2 W.; and secs. 23 and 24, T. 46 N., R. $1 \frac{1 / 2}{}$ W.

Cost analyses were made on all properties containing more than 35,000 tons of total reserves and probable potential resources. The $\mathrm{ThO}_{2}$ reserves that can be produced at less than $\$ 15 / \mathrm{lb}$ are 1,300 tons. In addition, 6,700 tons of probable potential resources fall in the same category. Reserves that can be produced between $\$ 15$ and
$\$ 30 / \mathrm{lb}$ amount to 300 tons of $\mathrm{ThO}_{2}$. Probable potential resources in this category are 1,000 tons. Reserves that can be produced at between $\$ 30 / \mathrm{lb}$ and $\$ 50 / \mathrm{lb}$ amount to 200 tons of $\mathrm{ThO}_{2}$. The probable potential resources in this category are 700 tons.

Analysis of production costs in veins large enough to mine indicates that $\mathrm{ThO}_{2}$ might be obtained for less than $\$ 30 / \mathrm{lb}$ in those having a grade of at least 0.15 percent $\mathrm{ThO}_{2}$; whereas, a cost between $\$ 30 / \mathrm{lb}$ and $\$ 50 / \mathrm{lb}$ is probable for those veins having an average grade of between 0.07 and 0.15 percent $\mathrm{ThO}_{2}$.

\section{HALL MOUNTAIN DISTRICT, IDAHO}

The Hall Mountain district lies just south of the Canadian boundary in the center of the Idaho panhandle. Thorium veins on the steep west side of the Hall Mountain intrude quartzite and diorite of Precambrian age. The quartzite belongs to the Prichard Formation of the Belt Supergroup, which is intruded by diorite sills of the Purcell Lava (Staatz, 1972a, p. 242). The known veins are found in a small area about 6,000 $\mathrm{ft}$ long by $1,000 \mathrm{ft}$ wide. This area is covered by brush and trees. Thick cover has limited the vein exposures, and the lack of a ready market for thorium has limited the amount of prospecting. Hence, although some of the thorium veins have been explored by bulldozer, some of them have been explored only by one or two small hand-dug pits. Even on the surface, none of the veins has been fully explored. thirteen deposits are known in this area. They include shear zones, parallel veinlets, veins, and a small irregular breccia body. These deposits are tabular and have been traced along strike for distances ranging from 6 to $900 \mathrm{ft}$. They vary in thickness from thin seams to $13 \mathrm{ft}$. Individual veins may also vary in thickness, and one long vein ranges from 0.6 to $10.8 \mathrm{ft}$ in thickness. Some of the known veins are too small to mine and process economically. The principal reserves in this district are concentrated only in a few veins.

The mineralogy of the Hall Mountain veins is simpler than that of veins in most other districts. The principal mineral in most Hall Mountain veins is quartz, although parts of some veins contain considerable granular calcite. Thorite is by far the most common thorium mineral. Allanite is also found in some places and is the second most 
abundant thorium-bearing mineral. Monazite, a common mineral in many vein districts, is ex. ceedingly rare. Minor amounts of chlorite, magnetite, limonite, and pyrite occur in many parts of the veins. In addition, 20 other minerals occur in minor amounts in some part of these veins, A more detailed account of the mineralogy and geology of the thorium veins has been reported previously by Staatz (1972a). The small amount of iron oxide minerals in these ores should make the milling of this ore easier and somewhat less costly than thorium ore from Lemhi Pass or the Wet Mountains.

The $\mathrm{ThO}_{2}$ content of samples from these veins ranges from 0.014 to 24 percent; the high-grade sample is a selected specimen. Tenor of individual veins varies erratically, and even the richest veins have some parts which are of low tenor. The average of several of the larger veins is nearly 5 percent $\mathrm{ThO}_{2}$, making these some of the highest grade veins in the United States. The total rare earth oxide content of these veins is much lower than that of the veins in other districts discussed in this report. The total rare earth oxide content of 12 samples from the Hall Mountain district ranged from 0.0011 to 0.197 percent (Staatz and others, $1974, p .680)$. In most other districts, the Tho $r$ to-total rare-earth oxide ratio ranges from about $1 / 2$ to 2 . In the Hall Mountain district; however, this ratio, from veins that are large enough to consider mining, varies from about 6 to 526. Another difference between the rare earths in other thorium vein districts and those in the Hall Mountain veins is that the former belong principally to the cerium rare-ear ths flanthanum, cerium, neodymium, praescdymium, samarium, and europium) and the latter to the yttrium group of rare-earths (gadolinium, terbium, dysprosium, holmium, erbium, thulium, ytterbium, lutetium, and yttrium). The content of the yttrium group of rare-earth oxides found in the Hall Mountain veins is about the same as in the Lembi Pass district, but differs from the latter in that most of cerium group of earths are missing at Hall Mountain.

Reserves in the Hall Mountain district are 4,580 tons of ThO and the probable potential resources are 26,300 tons of $\mathrm{ThO}_{2}$ (table 2). The $\mathrm{ThO}_{2}$ reserves in this district occur in 115,000 tons of vein material averaging 4.0 percent $T h O_{2}$. The probable potential resources are in 660,000 tons of rock of the same grade. A byproduct of rare earths probably would not be economical in this district because of the low total rare earth content. The reserves producible in this district at less than $\$ 15 / \mathrm{lb}$ are 4,540 tons of $\mathrm{ThO}_{2}$; the probable potential resources in this cost category are 26,100 tons of ThO $\mathrm{O}_{3}$. Actually, all of the above resources, because of the high tenor of the ore, are producible at less than $\$ 5 / \mathrm{lb}$ of ThO $\mathrm{T}_{2}$

\section{DIAMOND CREEK DISTRICT, IDAYO}

The Diamond Creek district is approximately $8 \mathrm{mi}$ north-northwest of the town of Salmon on the steep eastward-dipping slope of the Salmon River Mountains. The area is about $2,000 \mathrm{ft}$ above the Salmon River, which flows along the eastern edge of the mountains. Diamond Creek crosses the district, and the principal veins occur on its drainage. Known veins in this small district, however, are found in an area that is approximately $2 \frac{1}{2} \mathrm{mi}$ long by $0.5 \mathrm{mi}$ wide. Thorium veins were emplaced in to quartzite and siltite of Precambrian $Y$ age and into grancdiorite of the Idaho batholith of Cretaceous age. Most of the veins occur in the sedimentary rocks, which are approximately the same age as and, in part, lithologically similar to the rocks of the Belt Supergroup that are found farther north. The two groups of rocks were deposited in separate basins. The sedimentary rocks appear to be more favorable hosts than the igneous batholithic rocks as veins as much as $25 \mathrm{ft}$ thick have been found in the former, but they rarely exceed $2 \mathrm{ft}$ in the latter. Most of the prospecting consists of scattered bulldozer trenches and hand-dug pits. One of the larger veins was explored by a $25 \cdot \mathrm{ft}$ adit, and a vein also is exposed in the road bed of the Diamond Creek road. As most of the Diamond Creek area is soil covered, veins are only ex. posed in workings. The lack of development has limited the tracing of veins, and only eight veins have been identified in this region. The vein that is exposed in the Diamond Creek road between two forks of Diamond Creek is interpreted as being the southern extension of the larger vein exposed on the ridge on the north side of Diamond Creek. All the veins have similar attitudes, ranging in strike from about N. $10^{\circ} \mathrm{E}$. to N. $60^{\circ} \mathrm{E}$; all have steep dips. They follow irregular fractures in the country rock, and variations in strike of as much as $20^{\circ}$ have been noted on the same vein. The veins in this district show a general alinement 
along a northward-trending zone that is more or less parallel to their strike, and they probably were formed along one or more parallel shear zones. The eight veins have been traced along the surface for distances ranging from 110 to $2,560 \mathrm{ft}$. Some of these veins lie along strike from one another and they could either be part of the same vein or separate veins along the same structure. Evidence as to how far these veins extend generally is not available due to the lack of exploration in the intervening areas. The thorium veins vary in thickness from 0.5 to $25 \mathrm{ft}$; the largest vein in the district varies from 1.5 to $25 \mathrm{ft}$.

The veins of the Diamond Creek district are fine grained, limonitic, and similar in general appearance to many of those in the Lemhi Pass district. Quartz and limonite (generally goethite) make up a large part of these veins. Monazite is the principal thorium and rare-earth mineral. Thorium also occurs in minor amounts in some veins in brockite and thorite. In addition to these minerals, rare earths are found in minor amounts in some places in xenotime and bastnaesite. Fluorite, potassium feldspar, hematite, and biotite are locally abundant in some veins. In addition, small amounts of rutile, muscovite, montmorillonite, calcite, magnetite, plagioclase, malachite, pyrite, and gold were identified in one or more veins (Staatz, 1974, p. 498).

The $\mathrm{ThO}_{2}$ content of samples from these veins ranged from 0.04 to 1.71 percent. Only one sample contained more than 1 percent $\mathrm{ThO}_{2}$. The uranium content of seven samples was determined. Uranium ranged from 0.0003 to 0.01 percent. The thorium-to-uranium ratios of these seven samples vary from 6 to 150 . The lowest ratio comes from a vein too small to be economically mined. Rare earths are more abundant in this district than is thorium. Resource calculations of both the total rare-earth oxides and $\mathrm{ThO}_{2}$ indicate that the former is 5.8 times more abundant.

Total rare-earth oxide content of eight samples from this district varied from 0.59 to 5.51 percent. The light cerium group of rare earths (lanthanum, cerium, praesodymium, neodymium, samarium, and europium) made up most of the rare earths in most of these samples although one sample had almost as much yttrium group of rare earths (gadolinium, terbium, dysprosium, holmium, erbium, thulium, lutetium, ytterbium, and yttrium) as light. The thorium veins here have also been explored for gold, and this metal has been panned from altered zones along one of the veins. Three samples cut across one of the larger veins were assayed for gold, and contained $0.017,0.07$, and $0.348 \mathrm{oz} /$ ton (ounce per ton).

The veins for which resources were calculated in the Diamond Creek district range in average thickness from 0.5 to $10 \mathrm{ft}$. Their average grade is from 0.07 to 0.30 percent $\mathrm{ThO}_{2}$ and from 0.59 to 4.92 total rare-earth oxides. Total reserves are 250 short tons of $\mathrm{ThO}_{2}$ and 2,870 tons of total rare-earth oxides. Total probable potential resources are 13,000 tons of $\mathrm{ThO}_{2}$ and 75,500 tons of total rare-earth oxides. The total of both categories amounts to 13,250 tons of $\mathrm{ThO}_{2}$ and 78,370 tons of total rare-earth oxides. In the calculations of the probable potential resources, two veins having similar strike and dip and lying along the same shear zone were connected across a small valley. The overall average grade of the reserves and resources is 0.21 percent $\mathrm{ThO}_{2}$ and 1.22 percent total rare-earth oxides.

Three veins in this district were considered large enough to be mined. They contain a total of 12,230 tons of $\mathrm{ThO}_{2}$ that can be processed for less than $\$ 15 / \mathrm{lb}$ of which 30 tons are reserves and 12,200 tons are probable potential resources. This ore also contains 63,000 tons of rare earths. Another 775 tons of $\mathrm{ThO}_{2}$ is producible at between $\$ 15 / \mathrm{lb}$ and $\$ 30 / \mathrm{lb}$ of which 115 tons is reserves and 660 tons probable potential resources. None of the $\mathrm{ThO}_{2}$ is producible at between $\$ 30 / \mathrm{lb}$ and $\$ 50 / \mathrm{lb}$.

\section{BEAR LODGE MOUNTAINS DISTRICT, WYOMING}

The Bear Lodge Mountains district is just north of the Warren Peaks in the southern Bear Lodge Mountains. Veins are scattered over an area of about $5 \mathrm{mi}^{2}$ and about $5 \mathrm{mi}$ northwest of Sundance, Crook County, Wyo. The Bear Lodge Mountains have steep flanks, but the central part, where the veins occur, is a series of hills having but moderate relief. The southern part of the Bear Lodge Mountains consist of a core of Tertiary intrusive rocks that has domed up the surrounding sedimentary rocks of Paleozoic and Mesozoic age. The central core of igneous rocks is formed by multiple intrusions of alkalic igneous rocks, mainly trachyte and phonolite. This complex igneous body also contains minor amounts of 
syenite, nepheline syenite, and carbonatite. These three rock types increase in abundance with depth. After most of the igneous rock was intruded, the rocks in the central part of the core were fractured, altered, and many of the fractures were filled with vein material. The greater part of this material occurs in thin veinlets, which are described in the section on disseminated deposits. Some larger veins also were formed and are described here.

These veins are distinct tabular bodies having an average thickness of at least $0.2 \mathrm{ft}$. Twenty-six veins are known in this district and their exposed length is from a few feet to $450 \mathrm{ft}$. Exposures are generally poor and veins are seen only where exposed in workings. Thickening and thinning are common; one vein varies in thickness from 0.2 to $2.5 \mathrm{ft}$.

Average thicknesses of various veins in this district range from 0.2 to $5.5 \mathrm{ft}$. These veins tend to be irregular and lenticular. Their strike apparently is random. The only exception is that the two longest veins, which lie only several hundred feet apart, are parallel; none of the other veins, however, have a similar strike. Veins commonly change strike, as most of them were intruded along sinuous fractures. Dips are also highly variable, and dip measurements range from $25^{\circ}$ to $90^{\circ}$. All except one of the veins are in the Tertiary intrusive. The exception is a vein on the west side of the intrusive core that cuts the Pahasapa Limestone of Early Mississippian age.

The Bear Lodge Mountains veins generally are brown or black in color, but a few are pale green. Grain size is generally fine to submicroscopic. Although the principal gangue minerals are potassium feldspar, quartz, or cristobalite, the most common of the three is feldspar. Goethite, hematite, and various black manganese oxide minerals vein and impregnate the gangue minerals in many, but not all, of the veins. The principal thorium-bearing minerals are the phosphates, monazite and brockite. These minerals also contain rare earths. A common rare earth mineral is bastnaesite. Barite, rutile, brookite, magnetite, and fluorite are moderately common in these veins and, in addition, some 12 other minerals are sparsely present in a few veins.

The $\mathrm{ThO}_{2}$ content of 35 vein samples ranges from 0.013 to 1.37 percent. The average grade of these veins is considerably lower than those in the Lemhi Pass district, and more than a third of the samples contain less than 0.1 percent $\mathrm{ThO}_{2}$.
The uranium content of these veins is erratic but commonly is somewhat higher than that in most other vein districts. Uranium content of 27 vein samples ranges from 0.0005 to 0.027 percent. The thorium-to-uranium ratios of these samples vary from 1.6 to 183 , but most fall between 3 and 65 .

Rare earths are more abundant in these veins than thorium. The total rare earth oxides of 19 vein samples vary from 0.27 to 1.14 percent, and the average is almost one-half a percent. More than three-quarters of the samples contain more than 10 times as much rare earths as they do thorium. The relative amounts of the individual rare earths may be different in different veins. In this district, cerium is the most abundant lanthanide in some veins, neodymium in some, gadolinium in a few, and erbium in a few. Veins containing abundant monazite or bastnaesite have cerium or neodymium as their most common lanthanide. The presence of brockite in a vein indicates that it is gadolinium rich or erbium rich. Reserves and probable potential resources have been calculated for all the veins in the Bear Lodge Mountains. Veins exposed in only one place are considered to be only $25 \mathrm{ft}$ long instead of the 50 ft used in most other districts because of the overall tendency for veins to be short in the Bear Lodge Mountains. Reserves of the Bear Lodge veins total 55 tons of $\mathrm{ThO}_{2}$. The probable potential resources also equal 275 tons of $\mathrm{ThO}_{2}$. Reserves and resources of most veins are small, and those of 17 of the 26 individual veins do not exceed 10 tons of $\mathrm{ThO}_{2}$. The average grade of all veins ranges from 0.011 to 0.68 percent $\mathrm{ThO}_{2}$. Rare-earth resources are far more plentiful than those of thorium.

Most veins in this district are too small to support a viable mining operation. In addition, the grade of $\mathrm{ThO}_{2}$ is low when compared with that of most other vein districts. The ore resources of each of only two veins exceed 35,000 tons. The cost of producing $1 \mathrm{lb}$ of $\mathrm{ThO}_{2}$ at one of these properties exceeds $\$ 50$; the cost of producing $1 \mathrm{lb}$ of $\mathrm{ThO}_{2}$ at the other is just under $\$ 50$. Total reserves for the Bear Lodge veins that could be produced at between $\$ 30 / \mathrm{lb}$ and $\$ 50 / \mathrm{lb}$ are 15 tons of $\mathrm{ThO}_{2}$. The probable potential resources of veins in this category are 85 tons of $\mathrm{ThO}_{2}$. This $\mathrm{ThO}_{2}$ would come from 109,000 tons of ore having an average grade of 0.092 percent. In addition, this ore contains 6,780 tons of total rare-earth oxides. The rare-earth oxides make up 6.23 percent of the ore. 
MOUNTAIN PASS DISTRICT, CALIFORNIA

The Mountain Pass district is centered near Mountain Pass on Interstate Highway 15 between Las Vegas, Nev, and Barstow, Calif. Mountain Pass is $60 \mathrm{mi}$ southwest of Las Vegas in the northeast corner of San Bernardino County, Calif. The district is, in part a rolling upland about $5,000 \mathrm{ft}$ in altitude with several peaks and ridges rising about $1,000 \mathrm{ft}$ above the surface.

Thorium and rare earths occur in this district in veins, carbonatite dikes, and a massive carbonatite body. Rare earths are much more abundant than thorium in all three types of deposits. The massive carbonatite, the Sulphide Queen body, is the site of the world's largest rare-earth mine, which is operated by Molybdenum Corp. of America. The possibility of producing thorium from the Sulphide Queen carbonatite body is discussed in a separate section of this report. The thorium and rare-earth potential of the veins discussed here is smaller than the thorium and rare-earth potential of the other two types of deposits. All three types of deposit occur in a Precambrian terrain consisting of a well-foliated metamorphic complex intruded by syenite, shonkinite, and granite (Olson and others, 1954, p. 5-27). The rocks occur in a northwest-trending block about $18 \mathrm{mi}$ long by 4-5 mi wide that forms the east side of the Ivanpah Mountains, and is separated on the west from limestone and dolomite of Palezoic age, and volcanic rocks of Tertiary age by the Clark Mountain fault. Most of the thorium and rare-earth mineralization occurs in the southern half of the Precambrian block. The largest area of potassium-rich igneous rocks (syenite and shonkinite) lies about $1 \mathrm{mi}$ north of the highway that passes through Mountain Pass. Just south of these rocks is the large Sulphide Queen carbonatite body. Many of the carbonatite dikes also are concentrated in this general area. They become less common to the southeast. The veins occupy major and minor shear zones having a general northwesterly trend. The veins tend to be irregular and lenticular. They are more discontinuous here than in the Lemhi Pass or Wet Mountains districts. This discontinuous nature is well illustrated at the Windy group of claims where, along one shear zone, Shawe (1953, fig. 7) mapped 14 separate veins, and on the Ray-Welch-Willmore group where he mapped 11 veins along another shear zone. More than 35 veins are known in this district, ranging in length from about 10 to $1,000 \mathrm{ft}$. Most are short, and only three veins were traced for more than $300 \mathrm{ft}$. In thickness, they vary from a fraction of an inch to $12 \mathrm{ft}$. Veins commonly change in thickness through short distances, and one 60-ft vein in the Windy group varied from 0.5 to $12 \mathrm{ft}$ in thickness. All the veins are steeply dipping, generally at an angle of $60^{\circ}$ to $80^{\circ}$.

The veins in this district are distinguished from the carbonatite dikes by their total mineral composition. The veins consist principally of quartz and feldspar, and the dikes of carbonate minerals, although either may contain silica or carbonate minerals. Although the principal gangue minerals of the veins are quartz and microcline, all veins contain some calcite. Thorite is the principal thorium mineral and bastnaesite is the principal rare earth mineral. Bastnaesite is much more abundant than thorite and is commonly the principal heavy mineral. Other thorium-bearing and rare-earth-bearing minerals are allanite and monazite; barite is a common mineral in some veins. The iron oxide minerals, hematite, limonite, and magnetite occur in many of the veins, but generally make up less than 5 percent of any one. Ten other minerals were identified in minor amounts from these veins (Staatz, 1974, p. 498 ), some of which probably were derived from the country rock. The $\mathrm{ThO}_{2}$ content of samples from these veins ranged from 0.03 to 6 percent. The overall $\mathrm{ThO}_{2}$ grade of this district is lower than that of most other vein districts and the $\mathrm{ThO}_{2}$ content rarely exceeds 0.5 percent. The uranium content of 34 samples is from 0.0004 to 0.026 percent, and the thorium-to-uranium ratios of these samples is from 6 to 413 . The ratio of most samples falls between 25 and 175 . Some of the lower thorium-to-uranium ratios come from samples in which the thorium content is quite low. Thus, a decrease in this ratio does not necessarily signify an increase in the uranium content.

The Mountain Pass district is primarily a rareearth district, and the total rare-earth oxide content of 10 samples of vein material ranges from 1.96 to 8.94 percent. The total rare-earth content of these 10 samples is from 6.5 to 33 times more than the thorium content. Most of the rare earths are in bastnaesite, which contains little thorium. This mineral is made up predominately of the cerium group of rare earths, and cerium and lan- 
thanum are the principal rare earths in all the veins.

The total reserves of the Mountain Pass veins are 280 tons of $\mathrm{ThO}_{2}$, and the total probable potential resources are 1,500 tons of $\mathrm{ThO}_{2}$ for an aggregate total of 1,780 tons of $\mathrm{ThO}_{2}$. The average grade of the various veins is from 0.4 to 1.26 percent $\mathrm{ThO}_{2}$; most of the reserves fall between 0.1 and 0.54 percent $\mathrm{ThO}_{2}$. Rare-earth analyses are not available for all of these veins. Assuming that the average ratio of rare-earth oxide to $\mathrm{ThO}_{2}$ in the veins for which analyses are available is the same as in all veins, then the total of reserves and resources of rare-earth oxides for the above categories is approximately 29,100 tons.

Many of the veins in the Mountain Pass area are too small to support mining. Only four veins in this district were large enough to be economically evaluated. The $\mathrm{ThO}_{2}$ reserves in this district that can be produced at less than $\$ 15 / \mathrm{lb}$ amount to 175 short tons; this ore also contains 1,810 tons of total rare-earth oxides. In addition, another 685 tons of $\mathrm{ThO}_{2}$ are classified as probable potential resources. These resources also contain 7,200 tons of total rare-earth oxides. None of the veins large enough to mine have resources producible between $\$ 15 / \mathrm{lb}$ and $\$ 50 / \mathrm{lb}$ of $\mathrm{ThO}_{2}$.

\section{DISSEMINATED DEPOSITS}

Disseminated deposits tend to be large and of low grade when compared to the veins, and they can be of several types. They can be rock that is cut by many tiny thorium-rich veinlets, thoriumrich material disseminated in breccia pipes, or abnormally thorium-rich igneous bodies. Although large igneous bodies having a $\mathrm{ThO}_{2}$ content as low as $40 \mathrm{ppm}$ could be included under this heading, we have limited the present study to deposits having an average of $100 \mathrm{ppm} \mathrm{ThO}_{2}$ or greater. This eliminates such large bodies of granite as the Conway Granite of New Hampshire (Adams and others, 1962, p. 1901-1902) and granite of the Darby pluton of the Seward Peminsula, Alaska (Miller and Bunker, 1976, p. 373), both of which have an average $\mathrm{ThO}_{2}$ content of approximately $65 \mathrm{ppm}$. Higher grade granite has been reported in the small stock near Bull Creek canyon, Idaho, where isolated samples as high as $1,500 \mathrm{ppm}$ have been reported (Staatz, Bunker, and Bush, 1972, p. B54), but the overall average grade at Bull Creek canyon is only $35 \mathrm{ppm}$. Although granite bodies of this sort might be economic to mine at some time in the distant future, the relatively high cost of handling this low-grade material would not make mining economic until the still abundant high-grade sources are depleted.

Disseminated deposits form some of the world's large deposits of copper, molybdenum, and gold. Being large and low grade, they need both to be operated on a large scale and to have an active market for the commodity that they contain. As thorium has not been actively sold on the open market through 1977, there has been litthe incentive to explore for disseminated type thorium deposits. In spite of the lack of general interest in them, disseminated deposits have been noted in three widely separated areas: (1) Bear Lodge Mountains, Wyo., (2) Powderhorn district, Colorado, and (3) Hicks Dome, Ill. (fig. 1). The Hicks Dome area is in the northern part of the Illinois fluorspar district and the other two areas are better known as thorium vein districts.

The three listed disseminated deposits show differences in composition and depth of occurrence that would affect the type of mining and milling used. Most large disseminated deposits are mined by open pit, as this is the cheapest method of mining a large deposit. The deposits in the Bear Lodge Mountains and Powderhorn districts are, for the most part, exposed at the surface and could easily be mined with one or more open pits. The Hicks Dome deposit, however, is in a large cryptovolcanic structure, and little is exposed at the surface.

The composition and character of the disseminated deposits also differ. The Bear Lodge Mountains deposit consists of a composite trachyte-phonolite host rock that has been altered and cut by numerous thin veinlets contaiming both rare earths and thorium. At Powderhorn, the rock is a thorium-rich granite cut in places by veinlets. Thorium would be the principal product here. The Hicks Dome deposit is a breccia containing fragments of sedimentary rocks and having a mineralized matrix. Milling of material from the first two areas would be similar to that used for thorium veins.

The open-pit method is proposed for mining those disseminated bodies that occur at or near the surface. Open-pit methods also are applicable 
to mining the massive carbonatite bodies described in the following section of this report. In the open-pit method, rock is broken by drilling and blasting. It then is loaded using a front-end loader and hauled to the mill by truck. Sides of the pit are benched; bench height is $50 \mathrm{ft}$. We envision this type of mine operated by two shifts per day, 350 days a year.

Milling of the disseminated deposits of the Bear Lodge Mountains and the Powderhorn district would use the same mill design as for separating thorium and rare earths from the veins (p. 8, fig. 2).

The lands on which the Bear Lodge, Hicks Dome, and Powderhorn disseminated deposits occur are controlled by from one to several owners, and it has been necessary to consolidate the resource estimates of all disseminated deposits into an overall estimate. Resource data on the disseminated deposits are not as abundant as those on other types of thorium deposits. More definite data need to be obtained on the size of the disseminated deposits and many more samples should be collected. Thus, the resources in these deposits are not sufficiently well known to be called reserves. They also could not be considered as probable potential resources, because according to the Department of Energy classification, the system used in this paper, if a deposit does not have reserves, it does not have probable potential resources. It is clear, however, that large amounts of thorium do exist in this type of deposit, and we have classified these as "other resources." As used here, it refers simply to discovered resources for which a strong data base is not yet established.

The disseminated deposits in the Hicks Dome, Bear Lodge Mountains, and Powderhorn districts have a total of $2,200,000$ tons of $\mathrm{ThO}_{2}$ as "other resources." Some of these deposits would probably be developed as multiproduct operations. If $\mathrm{ThO}_{2}$, however, were the only product, then probably a third of the total resources could be produced competitively with uranium.

\section{HICKS DOME, ILLINOIS}

Hicks Dome is in Hardin County, Ill., about 35 mi northeast of Paducah, Ky., and $8 \mathrm{mi}$. north of Rosiclare, Ill. (fig. 1). The deposit was found during drilling by the St. Joseph Lead Co. of a hole near the apex of the dome (Brown and others, 1954). During this drilling, a mineralized breccia was found beneath a thick sequence of sedimentary rocks at a depth of $1,607 \mathrm{ft}$. The hole was still in breccia at its bottom at a depth of $2,944 \mathrm{ft}$.

Descriptions of the surface and subsurface character of the dome and its contained breccia are from Brown, Emery, and Myer (1954) and Heyl, Brock, Jolly, and Wells (1966). Identification and description of the mineralized breccia and the thorium and rare-earth minerals are from Trace (1960) and Brown, Emery, and Myer (1954). The aeroradiometric data used in delineating the periphery of the deposit are from Pitkin (1974).

Hicks Dome comprises more than 2,000 ft of Ordovician, Silurian, Devonian, and Mississippian sedimentary rocks, most of which are limestone, that have been pushed upward by an explosive intrusion of fluids. The Hunton Limestone of Devonian age is at the surface in the center of the dome, and younger rocks of Mississippian age are exposed on the flanks (fig. 3).

Total upward displacement of the sedimentary rocks over the crest of Hicks Dome is about 4,000 $\mathrm{ft}$ and the dome's diameter is approximately $9 \mathrm{mi}$. The dome lies on the crest and near the northwest terminus of a large northwest-trending anticline. The anticline and dome are transected by many northwest-trending faults.

Several small bodies of breccia are exposed on the top of the dome (fig. 3). These appear to be the uppermost extensions of the much larger body of explosion breccia found in the St. Joseph Lead Co. Hamp No. 1 drill hole. The center of the dome is outlined by a three- to four-fold increase in radioactivity that occurs over the apex area (Pitkin, 1974). The area of anomalous radioactivity at a flight level of about $400 \mathrm{ft}$ above the surface is delineated on the geologic map by a conspicuous increase in density of the isorads over the apex area.

The breccia consists mostly of limestone and dolomite fragments of the Paleozoic sedimentary rocks in a finer grained matrix of similar rock fragments, rounded quartz grains, and various hydrothermal minerals. The rounded quartz grains are believed to be derived from deeply buried St. Peter Sandstone of Ordovician age. The breccia body has been termed a diatreme (Brown and others, 1954; Heyl and Brock, 1961) and originated from an explosion associated with 


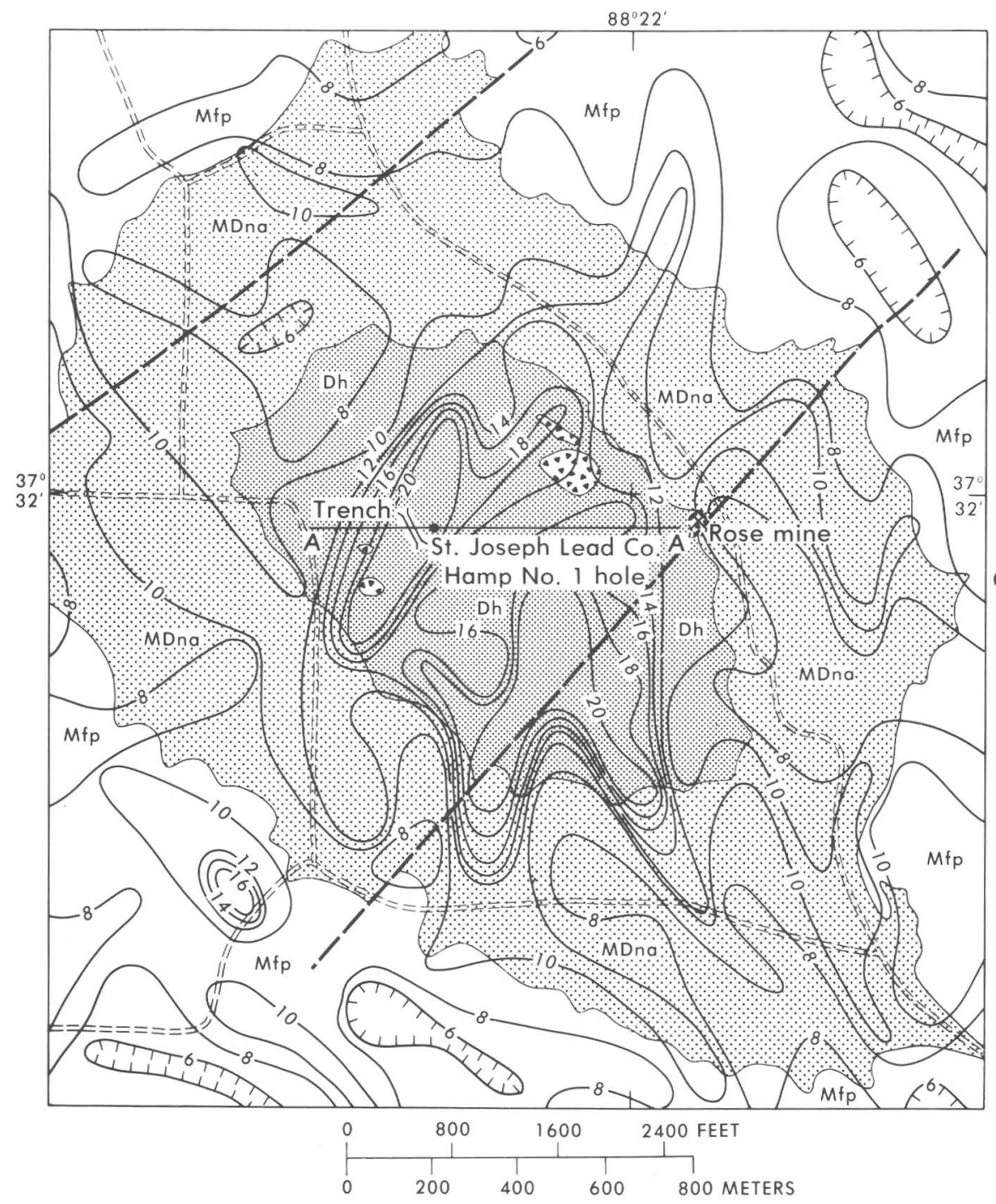

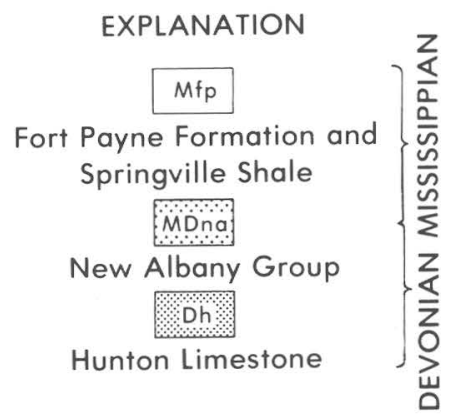

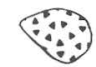

Explosion breccia

Approximate contact

$\longrightarrow 142-$

Contours drawn on lines of equal gamma-ray intensity of the $\mathbf{2 . 6 2}$ $\mathrm{MeV}$ (million electron volts) photopeaks of thallium -208 in the thorium -232 decay series. Contour interval 2 counts per second. Hatchured to indicate closed areas of lower gamma-ray intensity

Fault, approximately located

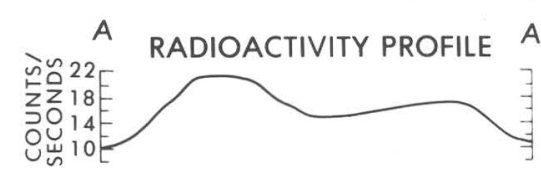

Figure 3.-Geologic and aeroradiometric map of Hicks Dome, Ill. Geology modified from Baxter and Desborough (1965, pl. 1), Baxter, Desborough, and Shaw (1967, pl. 1), and Brown, Emery, and Myer (1954, p. 892). Aeroradiometric contours from Pitkin (1974, pl. 1).

a deep-seated alkalic intrusion. Except for the hydrothermal mineralization, the diatreme is similar in character and composition to many of the diatremes in the midcontinent region as described by Zartman, Brock, Heyl, and Thomas (1967).

Brown, Emery, and Myer (1954) noted that the brecciated zone between the 1,607-ft depth and the bottom of the drill hole was mineralized. The mineralization occurs in the matrix of the breccia, as incipient veinlets, and as replacement of limestone and dolomite fragments. Hydrothermal minerals exposed in this hole and in a nearby surface trench $260 \mathrm{ft}$ long (fig. 3) have been reported on by Brown, Emery, and Myer (1954, p. 897-899) and Trace (1960). These minerals in- 
clude fluorite, calcite, quartz, barite, pyrite, sphalerite, galena, apatite, florencite, and monazite.

Sample data came from vein and brecia material exposed in the 260 -ft long trench (Trace, 1960 , p. B64) and from the St. Joseph Hamp No. 1 hole. Many more samples from many drill holes are needed to give an accurate picture of distribution of the radioactive minerals and the grade of this possible deposit as well as to verify whether the size of the anomaly on the radiometric map (fig. 3) in fact is a reasonable indication of the presence of a large subsurface breccia mass.

Radiation as indicated by spectrographic analyses of the drill core samples (Trace, 1960, p. B64) and from the radiometric study (Pitkin, 1974) is principally due to thorium. Eight samples, 25-30 ft long, were taken of core from the Hamp No. 1 hole in the breccia. These samples, which represent only $210 \mathrm{ft}$ of the total $2,337 \mathrm{ft}$ of breccia cut, were analyzed both by a semiquantitative spectrographic method (Trace, 1960 , p. B64) and by a radiometric method (Brown and others, 1954, p. 899). The first method identifies various elements and gives a semiquantitative value of each. The second gives a quantitative value for the amount of uranium present if the radiation is due to uranium and if the uranium is in equilibrium. The spectrographic and aeroradiometric data, however, indicate that the radiation is due to thorium. The amount of thorium actually present can be calculated from the equivalent uranium values. $\mathrm{ThO}_{2}$ of these eight samples ranges from 0.007 to 0.18 percent.

The resource calculation included in the generalized figure for disseminated deposits is based on assumptions expressed above concerning the probable extent of the subsurface breccia mass and its probable content of thorium minerals. The interpreted breccia mass may not be uniformly developed in lateral extent or depth, and its content of thorium minerals may be extremely uneven; thus, the resource calculation is recognized as highly speculative but is regarded as embodying geologic interpretation and extrapolation.

\section{BEAR LODGE MOUNTAINS, WYO.}

The Bear Lodge Mountains disseminated deposit is in the southern Bear Lodge Mountains about $5 \mathrm{mi}$ northwest of Sundance, Crook Coun- ty, Wyo. (fig. 1). This is the same area in which the thorium-bearing veins in the Bear Lodge Mountains occur. The host rock of the disseminated deposit consists of alkalic intrusive rocks of middle Tertiary age. These rocks, which are principally trachyte and phonolite, make up an igneous complex that was formed by a series of intrusions during a period of at least 20 million years. The rocks of the igneous complex intruded Paleozoic and Mesozoic sedimentary rocks that they not only partly replaced but also forced up into a dome. The dome itself underlies an area about $8 \mathrm{mi}$ long and $6 \mathrm{mi}$ wide. The alkalic igneous core of this dome has an oval outcrop pattern and is exposed over an area approximately $51 / 2 \mathrm{mi}$ long and $2 \frac{1}{2} \mathrm{mi}$ wide. After most of the igneous rock was intruded, a period of stress and alteration occured during which some of the igneous rock was fractured and altered, and the numerous fractures were filled with vein material. Most of the veinlets are thin, ranging from fracture coatings to veins 1/4-in: thick. Some are thicker, and some are even large enough to be mined as separate veins. The fractures and the emplaced veinlets are numerous, crisscrossing, and strike in many different directions. Dips are variable.

The veinlets are gray, black, or brown. The color generally depends on the presence and amount of various iron and manganese oxides. The manganese oxide minerals, pyrolusite and cryptomelane, or finely disseminated specular hematite, give the veinlets a black color; the presence of limonite, generally goethite, tends to color the veinlets shades of brown. Only when these oxides occur in small amounts does the vein show the color of other minerals present. The mineralogy of the veinlets is similar to that of the veins. The minerals in the disseminated deposit are those of both the country rock and the veinlets. Sanidine is one of the commonest minerals present, as it is abundant both in phenocrysts in the host rock and in gangue in the veinlets. Another abundant material might be called "groundmass." This is the altered glassy or partly recrystallized groundmass of the host rock, which may originally have been glass but has since recrystallized into minute undistinguishable grains. In places the groundmass contains discrete mineral grains that have subsequently been altered to unrecognizable minerals. 
Although feldspar is the principal gangue mineral in many of the veinlets, quartz or cristobalite is more abundant in some. Monazite, thorite, and brockite are the identified thorium-bearing minerals. In addition, many veinlets contain small amounts of barite, rutile, brookite, and magnetite. Some veins also contain minor amounts of fluorite, xenotime, sphalerite, and pyrite.

The amount of $\mathrm{ThO}_{2}$ in the disseminated deposit varies from place to place. In part, this variation is because the outer edges contain fewer veinlets; in part, it is due to variations in the number of veinlets within the body. Completely unaltered trachyte and phonolite are not common, but in areas where they are least altered, as near the south end of the core of the igneous complex and in separate bodies peripheral to the core, these rocks contain from 19 to $46 \mathrm{ppm} \mathrm{ThO}_{2}$. The grade of rock containing disseminated veinlets increases from about $46 \mathrm{ppm} \mathrm{ThO}_{2}$ for unmineralized rocks to about 1,200 ppm for rock containing many veinlets. These grade figures do not include solid vein material as described in the section on "Veins," which can be of much higher grade. Rare earths are much more abundant than thorium in the disseminated deposit. The total rare-earth oxide content of 52 samples of rock containing veinlets varies from 430 to $32,000 \mathrm{ppm}$ and has an average of about $2,300 \mathrm{ppm}$. Most of the analyses, however, range from 1,200 to 18,000 ppm total rare-earth oxides.

The part of the intrusive complex that contains numerous small veinlets is an area that extends for about $1-1 / 2 \mathrm{mi}$ to the north from the northernmost of the Warren Peaks, and is a little more than $1 \mathrm{mi}$ wide. In other parts of the intrusive complex, especially to the south, the fracturing and alteration diminish. The area of veining and thorium mineralization can be separated from the less mineralized areas by its radioactivity. The area of thorium mineralization was first outlined by making a radiometric map using a hand-held scintillation counter (fig. 4). Unfortunately, the measurements include not only those obtained from thorium radiation, but from that of potassium and uranium as well. All three have an appreciable effect on the total radioactivity. Potassium feldspar occurs both in the host rock and in the veinlets. In the altered and veined part of the intrusive complex, the potassium content is more or less constant and its average is approx* imately 10 percent. Although the amount of radioactive $\mathrm{K}^{40}$ in potassium is small in these potassium-rich rocks, the radioactivity due to this element would be about equal to $270 \mathrm{ppm}$ of $\mathrm{ThO}_{2}$. The uranium content of these veined rocks varies from 8 to $346 \mathrm{ppm}$, and the thorium-touranium ratios of various samples taken ranges from 0.4 to 30 . The uranium content is greater than in most other vein districts. The amount of radioactivity due to uranium is approximately 5.7 times that created by an equal amount of thorium. Hence, a sample containing 12 times as much thorium as uranium would have about onethird of its radiation due to uranium. Although thorium is overall the most important radioactive element, the presence of relatively large amounts of radiation from potassium and uranium could mask its presence. To answer the question of whether the relative proportions of thorium can be discerned on a radioactive map, a graph was made showing thorium content versus total radioactivity (fig. 5). Points shown on figure 5 represent the thorium content of individual samples plotted against their total radioactivity. The thorium content of most samples increases in proportion to total radioactivity, and the graph shows a linear trend. Therefore, a counter can be used to outline the area of largest thorium content (fig. 4). Other samples of the intrusive complex were taken within this area and analyzed for thorium (fig. 5). From these data, a second contour map was made using a contour interval of $100 \mathrm{ppm}$ thorium. Examination of the shape of the 100 -ppm contour shows that it resembles the 600-counts-per-minute total-radiation contour measured with the scintillation counter (fig. 4).

The thorium-contour map made from the analytical data has three areas where the quantity of this element exceeds $220 \mathrm{ppm}$. Each area is considered a possible site for an open-pit mine for mining thorium and rare earths. As only a few feet of soil covers most of the area, there is little overburden to remove. Although some sampling has been carried out in the three areas, many more analyses are needed to obtain a valuable average grade. Grades of these areas, however, 


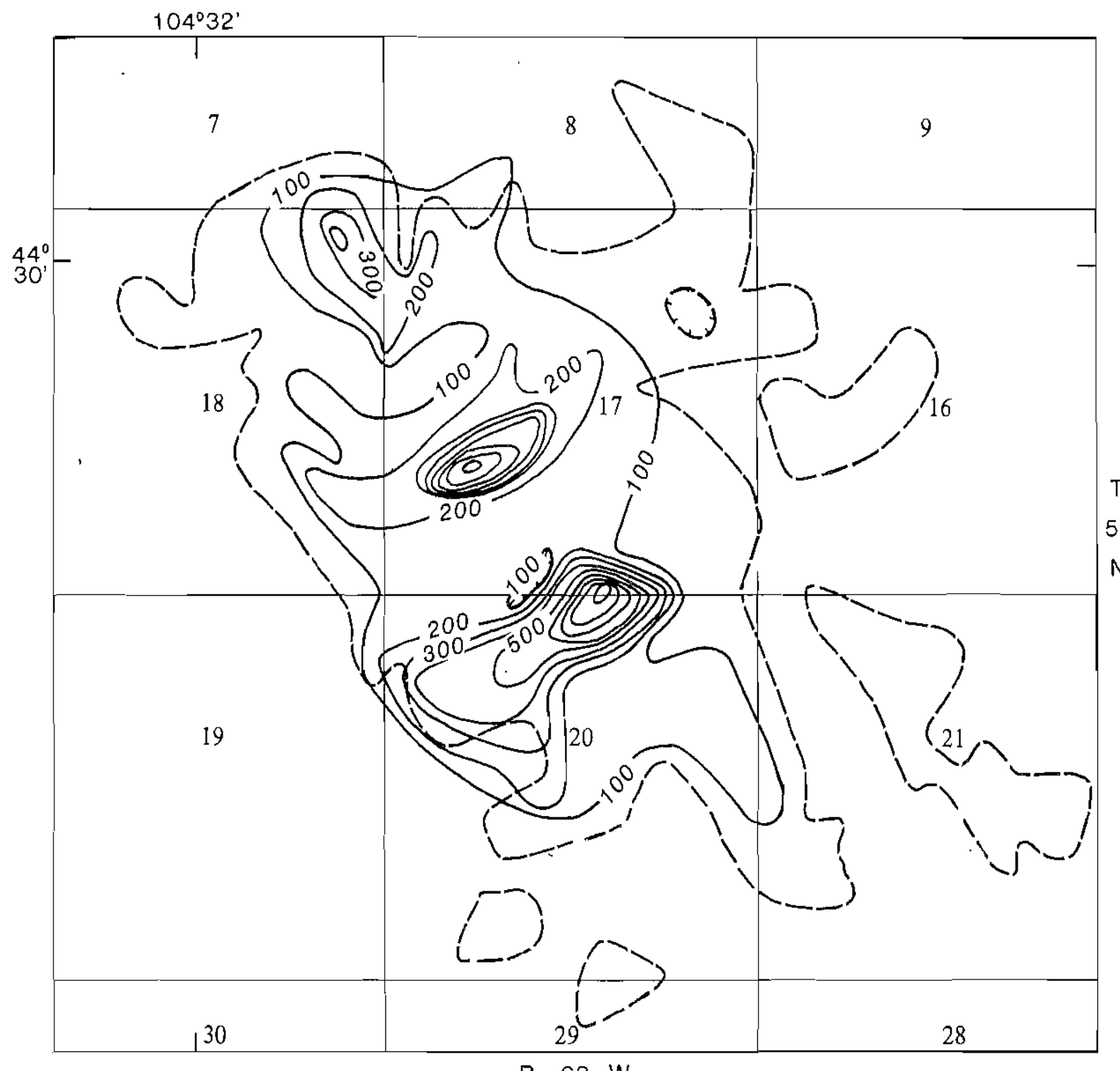

$\mathrm{T}$.

52

N.

R. $63 \mathrm{~W}$.

\section{EXPLANATION}

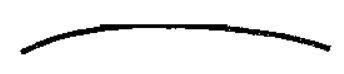

Thorium contour --Drawn on points of equal thorium content. Contour interval $100 \mathrm{ppm}$ thorium. Hachured to indicate closed area of lower thorium content

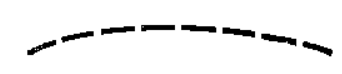

Radloactivity contour--Drawn on all points that have a total-gamma radioactivity plus high-energy beta radioactivity of 600 counts per second. Hachured to indicate closed area of lower radioactivity

FIGURE 4.-Thorium-content and radiometric map of the northern part of the alkalic intrusive core in the Bear Lodge. Mountains, Wyo. 


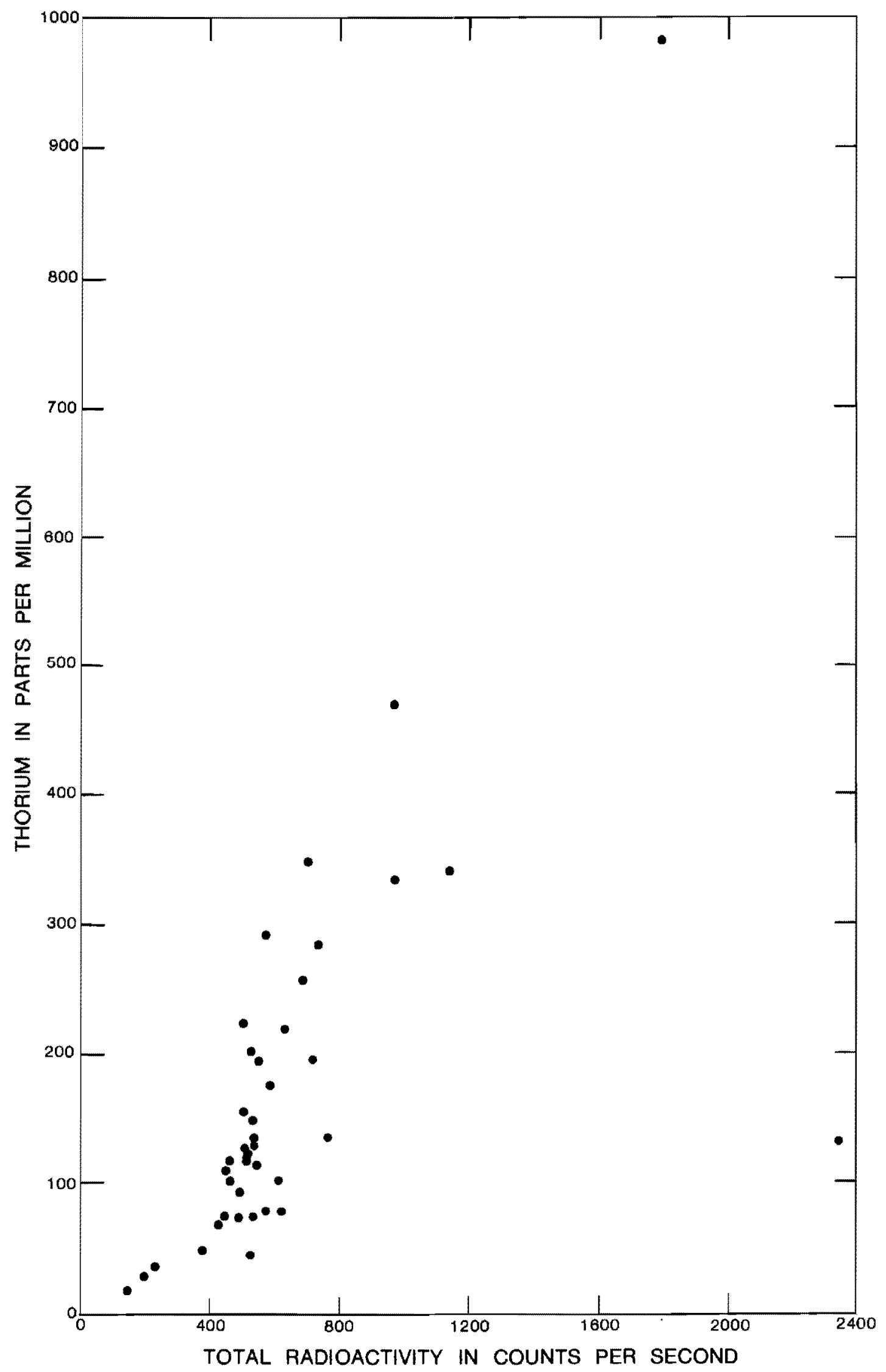

FIgURE 5.-Relationship of thorium content to total radioactivity in samples from the Bear Lodge Mountains, Wyo. 
based on available samples are as follows: (1) The northern area has an average grade of 0.023 percent $\mathrm{ThO}_{2}$ and 0.75 percent combined rare-earth oxides, (2) the central area has an average grade of 0.042 percent $\mathrm{ThO}_{2}$ and 1.71 percent combined rare-earth oxides, and (3) the southern area has an average grade of 0.035 percent $\mathrm{ThO}_{2}$ and 1.35 percent combined rare-earth oxides. Drilling in secs. 17 and 18 (fig. 4) indicates that the veining extends at least $1,200 \mathrm{ft}$ below the surface. Although mineralization is known to this depth, grade data are scarce.

POWDERHORN, COLO.

A fine-grained granite that in places is abnormally radioactive occurs within $2 \mathrm{mi}$ of the south and west margins of the alkalic igneous complex at Iron Hill and has been mapped by Olson (1975) and Hedlund and Olson (1975). The granite occurs in dikelike bodies and irregular small plutons as much as $1,600 \mathrm{ft}$ wide and in two larger bodies $21 / 2 \mathrm{mi}$ long and $2,000-4,000 \mathrm{ft}$ wide. The granite mostly is fine grained, some is medium grained, and locally it is porphyritic. It is composed of microperthitic microcline, quartz, plagioclase, and biotite. Associated with the granite are two bodies of melasyenite, $200-400 \mathrm{ft}$ wide. The finegrained granite was considered by Hunter (1925) to be a variety of the Powderhorn Granite of Precambrian age, but the fine-grained granite intrudes the Powderhorn Granite (Olson, 1975). Furthermore, a considerable age difference between the two granite types is likely, as the finegrained granite is little deformed in comparison with the adjoining gneissic coarse-grained Powderhorn Granite.

The fine-grained granite is fenitized in places, as shown by potassium feldspathization and bluegreen amphibole veinlets, and it is cut by carbonatite and lamprophyre dikes and by thorium veins that are probably related to the complex at Iron Hill. Some of the fine-grained granite occurs in crudely arcuate plutons around the southern part of the complex at Iron Hill. These forms, which are suggestive of ring dikes, may indicate a link between the fine-grained granite bodies and the complex.

Not all the fine-grained granite bodies are abnormally radioactive. Those with abnormal radioactivity occur in two areas: (1) along the western edge of the complex at Iron Hill for about $2 \mathrm{mi}$ to its southern tip, and (2) in an area 2,000 to $6,000 \mathrm{ft}$ south of the central part of the southern edge of the complex. In the first area is a pluton about $2 \mathrm{mi}$ long and 4,000 ft wide. This pluton has been strongly fenitized adjacent to the complex. Part, but not all, of this body is abnormally radioactive. The extent of abnormal radioactivity is not well known, but in an area adjacent to the road down Cebolla Creek, readings on a gammaray spectrometer indicated that the partly fenitized granite here contains from 40 to $300 \mathrm{ppm}$ $\mathrm{ThO}_{2}$. An average of this area would be about 100 ppm. The thorium-rich part of the granite is at least $400 \mathrm{ft}$ wide here but probably makes up only a small part of the entire granite body.

In the second area are four plutons that range from 1,000 to $3,500 \mathrm{ft}$ in length and are 300 to $1,600 \mathrm{ft}$ wide. These plutons have been explored by numerous bulldozer trenches, especially on the sides of the road up Beaver Creek, which cuts through the center of the area. The radioactivity of these granite bodies was measured in the field using a gamma-ray spectrometer, but eight samples also were analyzed using a laboratory gamma-ray spectrometer. The $\mathrm{ThO}_{2}$ content of these rocks varies considerably, but large parts of these granite bodies contain from 115 to $225 \mathrm{ppm}$ $\mathrm{ThO}_{2}$, although some of the most radioactive areas yield as much as $1,140 \mathrm{ppm} \mathrm{ThO}_{2}$. The eight samples analyzed in the laboratory had from 35 to $320 \mathrm{ppm} \mathrm{ThO}_{2}$. The parts of the granite bodies having the most radioactivity are characterized by red and yellowish-brown limonitic staining and by rusty-weathering black siliceous veinlets and brown limonitic veinlets, which occur along joint and shear planes.

The greater part of the known thorium resources occurs in the four small plutons directly south of the complex at Iron Hill where the largest abnormally radioactive area is at least $600,000 \mathrm{ft}^{2}$ in size.

\section{MASSIVE CARBONATITE BODIES}

Massive carbonatites have not been prospected as sources of thorium. The principal reason is that the grade is low compared to nearby vein deposits. The size generally is large, however, and as these carbonatites commonly are rich sources of other metals such as niobium and rare earths, 
any thorium that might be recovered from massive carbonatites likely would be a byproduct.

Carbonatites are not common, although they are known from at least 13 localities in the United States. Most of them are narrow dikes. Four massive carbonatites are known in the United States: (1) Iron Hill carbonatite in the Powderhorn district of Colorado, (2) Sulphide Queen carbonatite in the Mountain Pass district of California, (3) carbonatite in the Magnet Cove district, Arkansas, and (4) Elk Creek carbonatite in Nebraska. The Iron Hill carbonatite underlies an area of more than $1 \mathrm{mi}^{2}$. The Sulphide Queen carbonatite is an irregular body a little less than $0.5 \mathrm{mi}$ long. It is the site of the largest rare-earth mine in the United States. These two massive carbonatites are evaluated for thorium in this section of the report. The Magnet Cove carbonatite was not considered because it is small and has little thorium. Although thorium was looked for in spectrographic analyses of 10 samples from this carbonatite, it was not found (Erickson and Blade, 1963, p. 35). The Elk Creek carbonatite was discovered by the Nebraska Geological Survey when they were drilling at a geophysical anomaly on the Nemaha anticline. It is overlain by more than $600 \mathrm{ft}$ of sedimentary rocks (Brookins and others 1975, p. 80). This carbonatite also was not evaluated, as little data are available as to its size, mineralogy, and grade of thorium.

The Iron Hill and Sulphide Queen carbonatites (fig. 1) differ in size, topographic exposure, and mineral content. Their vertical dimension probably is large; the Iron Hill carbonatite forms a hill having a vertical exposure of more than 1,000 ft. The two carbonatites are projected to different depths in the resource calculations. The depth used in the large Iron Hill carbonatite includes the hill plus an additional $800 \mathrm{ft}$ below its lowest topographic exposure. The smaller Sulphide Queen carbonatite is projected a total distance of $1,000 \mathrm{ft}$, of which half is calculated as reserves and half as probable potential resources. A ton" nage factor of $11.4 \mathrm{ft}^{3} / \mathrm{short}$ ton was used in converting carbonatite volume to carbonatite weight.

Mining of the Iron Hill carbonatite would be by open pit, but would differ somewhat from the standard open pit procedure, as most of Iron Hill could be removed first by mining from the sides of the hill before a standard benched pit was started downward. The Sulphide Queen carbonatite is being mined as an open pit operation. The open-pit mining and costs entailed would be similar to those previously described under the section on disseminated deposits.

Milling of ore from these iwo properties would be somewhat different because the principal economic product at Iron Hill probably would be niobium and at the Sulphide Queen it is rare earths. Furthermore, the principal thoriumbearing minerals at the two localities are not the same. Milling costs also would be different because capital costs at Iron Hill would include the cost of a complete mill built for recovery of thorium and other metals. At the Sulphide Queen, on the other hand, a mill built to recover rare earths already exists, so capital costs would cover only the costs of a thorium circuit.

Pyrochlore is known to contain thorium in the Iron Hill carbonatite, and at present it is the only known source here of this element. This mineral also contains both rare earths and uranium. Hence, in the mill design used for this property, it was assumed that pyrochlore was not only the major source of the niobium, but of the thorium, rare earths, and uranium as well. Pyrochlore in the carbonatite would be recovered by a flotation process similar to that presently being used to recover this mineral at Oka in Canada (Carbonneau and Caron, 1965 , p. 75-78). Pyrochlore concentrates are treated with chlorine gas at high temperature, causing the niobium to be volatized. It then is precipitated by hydrolysis. The thorium, rare earths, and uranium are extracted from the residue by an acid leach-solvent method. This separation method of the various metals from the pyrochlore is based on limited laboratory tests. These tests indicate that mill recovery of $\mathrm{Nb}_{2} \mathrm{O}_{3}, \mathrm{ThO}_{2}, \mathrm{U}_{3} \mathrm{O}_{4}$, and total rareearth oxides would be about 80 percent. Possibly a better recovery could be achieved in plant practice. Capital and operating costs were based on a mill having a maximum handling capacity of 10,000 tons per day and having a minimum mill life of $15 \mathrm{yr}$. The actual size of any mill built would depend on the demand for both niobium and thorium. Using a mill operating at maximum capacity of $3,500,000$ tons a year 110,000 tons $X$ 350 days), the deposit would last for many years. Increased demand could be met by building more 
similar mills or larger mills. For larger mills, both the capital and operating cost per ton of $\mathrm{ThO}_{2}$ probably would be a little lower.

Most of the thorium in the Sulphide Queen carbonatite apparently is in monazite, which is fairly common in some parts of this body. The mill operation here would separate out the monazite and then extract the $\mathrm{ThO}_{2}$ from it. To do this, only the cost of adding a circuit to Molybdenum Corp. of America's present operation was calculated. In their mill, bastnaesite, the principal rare earth ore mineral, is separated from the carbonate gangue by flotation (Harrah, 1967; Johnson, 1966). Most of this concentrate is dried and then leached using 30-percent hydrochloricacid solution, which dissolves the rare earths from the bastnaesite. Monazite probably floats with the bastnaesite, as oleic acid, which is used by Molybdenum Corp. of America as the flotation promoter, and is also a flotation promoter for monazite. The monazite probably would not dissolve in the acid and could be recovered from the acid leach residue. Based on these assumptions, a circuit was designed to recover $\mathrm{ThO}_{2}$ from the acid residue. In this circuit, monazite would be first electrostatically separated from the residue. The monazite would then be acid leached and $\mathrm{ThO}_{2}$ and total rare earth oxides would be recovered from the leach solution by solvent extraction and precipitation. The mill recovery of $\mathrm{ThO}_{2}$ in this circuit is estimated to be about 70 percent. Capital cost for the extra mill circuit would be about $\$ 1,500,000$.

The two massive carbonatites evaluated in this paper (Iron Hill and Sulphide Queen) have a total of 165,100 tons of $\mathrm{ThO}_{2}$ in reserves and probable potential resources. If only $\mathrm{ThO}_{2}$ is recovered, none of it could be produced at less than $\$ 30 / \mathrm{lb}$ and only about 12 percent (that occurring in the Sulphide Queen carbonatite) would be producible at between $\$ 30$ and $\$ 50 / \mathrm{lb}$. If other economic products were recovered, then 83 percent of this total or 137,500 tons of $\mathrm{ThO}_{2}$ would be producible at less than $\$ 30 / \mathrm{lb}$. Little would be producible at between $\$ 30 / \mathrm{lb}$ and $\$ 50 / \mathrm{lb}$ of $\mathrm{ThO}_{2}$. Thus, the $\mathrm{ThO}_{2}$ produced from massive carbonatites should be considered principally as a byproduct, and it is dependent on the markets for rare earths and niobium. The amounts of $\mathrm{ThO}_{2}$ and estimated cost of production for the two massive carbonatites is summarized in table 3 .

\section{IRON HILL BODY, POWDERHORN DISTRICT, COLORADO}

The Iron Hill carbonatite, the largest exposed massive carbonatite in the United States, is part of the 570 million-year-old alkalic complex at Iron Hill, near Powderhorn, Colo. (Olson and others, 1977). The complex, which consists primarily of pyroxenite, uncompahgrite, ijolite, nepheline syenite, and carbonatite intrudes Precambrian X Powderhorn Granite that is strongly fenitized for at least $0.5 \mathrm{mi}$ away from the contact. The complex is, in turn, intruded by carbonatite dikes, magnetite-perovskite segregations, and diabase dikes of Ordovician or Cambrian age. Tertiary ash-flow tuffs and a variety of Tertiary and Quaternary sedimentary deposits cover parts of the complex.

The complex of alkalic rocks at Iron Hill and the surrounding area have been mapped by Larsen (1942), Hedlund and Olson (1975), and Olson (1975). The mineral-resource potential of the complex of alkalic rocks has been discussed by Olson and Wallace (1956), Rose and Shannon (1960), and Temple and Grogan (1965). Anomalous amounts of thorium, 5 to 10 times greater than background, were reported at two localities within the massive carbonatite by Olson and Wallace (1956). The massive carbonatite also contains known reserves of niobium-more than 100,000 tons of $\mathrm{Nb}_{2} \mathrm{O}_{5}$ in rocks averaging at least 0.25 percent $\mathrm{Nb}_{2} \mathrm{O}_{5}$ (Temple and Grogan, 1965). Abundant rare earths also are found in the carbonatite.

A study was made to determine the abundance and distribution of thorium in the massive carbonatite at Iron Hill. Field measurements of thorium abundance were made at 151 stations within the directly adjacent to the massive carbonatite using a portable differential fourchannel gamma-ray spectrometer. This instrument uses a 3-in. diameter by 3 -in. thick $\mathrm{NaI}$ crystal as a detector. Counting times at each station were of 2 -minute duration. These measurements were compared with those from 28 samples that were analyzed for thorium in the laboratories of the U.S. Geological Survey. The accuracy of the field method is difficult to evaluate but, as a guess, probably does not differ from the laboratory method by more than about 25 percent.

The massive carbonatite at Iron Hill consists primarily of dolomitic carbonatite, but several 
TABLE 3.- $-\mathrm{ThO}_{2}$ reserves and probable potential resources in short tons from two massive carbonatite bodies in the United States.

\begin{tabular}{|c|c|c|c|c|c|c|c|c|}
\hline \multirow[b]{2}{*}{ District } & \multirow[b]{2}{*}{$\begin{array}{l}\text { Total } \\
\text { reserves }\end{array}$} & \multirow[b]{2}{*}{$\begin{array}{l}\text { Total probable } \\
\text { potential } \\
\text { resources }\end{array}$} & \multicolumn{2}{|c|}{$\begin{array}{l}\text { Total producible at } \\
\text { less than } \$ 15 / 10\end{array}$} & \multicolumn{2}{|c|}{$\begin{array}{l}\text { Total producible at } \\
\text { between } \$ 15 \text { and } \$ 30 / 1 \mathrm{~b}\end{array}$} & \multicolumn{2}{|c|}{$\begin{array}{l}\text { Total producible at } \\
\text { between } \$ 30 \text { and } \$ 50 / 1 b\end{array}$} \\
\hline & & & Reserves & $\begin{array}{l}\text { Probable } \\
\text { potentia? } \\
\text { resources }\end{array}$ & Reserves & $\begin{array}{l}\text { Probable } \\
\text { potential } \\
\text { resources }\end{array}$ & Reserves & $\begin{array}{l}\text { Probable } \\
\text { potential } \\
\text { resources }\end{array}$ \\
\hline \multicolumn{9}{|c|}{ Where $\mathrm{ThO}_{2}$ is the sole product } \\
\hline \multirow{2}{*}{$\begin{array}{l}\text { Iron Hill, } \\
\text { Colo........ } \\
\text { Sulphide Queen, } \\
\text { Calif....... }\end{array}$} & 31,080 & 0 & 0 & 0 & 0 & 0 & 0 & 0 \\
\hline & 9,750 & 9,750 & 0 & 0 & 0 & 0 & 9,750 & 9,750 \\
\hline \multirow[t]{2}{*}{ Total....... } & 40,830 & 124,650 & 0 & 0 & 0 & 0 & 9,750 & 9,750 \\
\hline & \multicolumn{6}{|c|}{ Where other economic products are recovered } & & \\
\hline \multirow{2}{*}{$\begin{array}{l}\text { Iron } H i l l, \\
\text { Colo........ } \\
\text { Sulphide Queen, } \\
\text { Cal if........ }\end{array}$} & 31,080 & 114,900 & 31,080 & 87,300 & 0 & 0 & 0 & 0 \\
\hline & 9,750 & 9,750 & 9,750 & 9,750 & 0 & 0 & 0 & 0 \\
\hline Total....... & 40,830 & 124,650 & 40,830 & 97,050 & 0 & 0 & 0 & 0 \\
\hline
\end{tabular}

calcitic variants occur in the intrusion. The fresh light-gray carbonatite typically weathers dark brown. Variations in grain size are common. The carbonatite is cut by martite-apatite veins, some of which are more strongly radioactive than the neighboring carbonatite. Linear zones occupied by weakly radioactive jasper appear to represent silicified fracture zones.

The most abundant mineral in the carbonatite is dolomite; ankerite, siderite, and calcite also occur. Pyrochlore is the dominant niobium mineral and fluorapatite probably is the most important rare-earth-bearing mineral. Magnetite, ilmenite, hematite, goethite, pyrite, rutile, zircon, monazite, fluorite, biotite, and barite also are constituents of the carbonatite (Temple and Grogan; 1965; Nash, 1972).

The 28 samples of carbonatite analyzed for thorium also were analyzed for radium-equivalent uranium (RaeU) and potassium using a laboratory gamma-ray spectrometer and for 61 elements by the six-step semiquantitative spectrographic method. Certain characteristics of the Iron Hill carbonatite become apparent when the average abundances of elements in the 28 samples are compared with elemental abundances in igneous rocks of the upper continental crust (Wedepohl, 1971, p. 65). The following abundances were noted: barium, lanthanum, niobium, phosphorus, cerium, calcium, and total rare-earth elements are at least 10 times more abundant in the carbonatite; manganese and strontium 5-10 times more abundant; and beryllium, magnesium, uranium, and thorium are 3-5 times more abundant. The other elements are only slightly more abundant or slightly depleted. These elements constitute the assemblage of minor and trace elements that is characteristic of carbonatites in general (Heinrich, 1966).

Iron Hill is made up entirely of the massive carbonatite. Other rock types form the low areas around the hill. The high point on the hill is more than $1,000 \mathrm{ft}$ above the west side of the carbonatite body where it crops out along Cebolla Creek. The amount of material in the hill that projects above the surrounding land surface was calculated by making seven evenly spaced cross sections across the hill, measuring the area in each, and multiplying the average area in pairs of sections by the distance between them. The hill was found to contain $722,700,000$ tons of carbonatite. The average grade, based on measurements at 151 stations, is 0.0043 percent $\mathrm{ThO}_{2}$. This amount of rock would contain 31,080 tons of $\mathrm{ThO}_{2}$. The average grade of various other metals in the carbonatite was obtained from analytical data on the 28 samples. These grades are 0.057 percent for $\mathrm{Nb}_{2} \mathrm{O}_{5}, 0.397$ percent for total rare earth oxides, and 0.00127 percent for $\mathrm{U}_{3} \mathrm{O}_{8}$. The hill contains 411,900 tons of $\mathrm{Nb}_{2} \mathrm{O}_{5}$, $2,865,000$ tons of total rare-earth oxides, and 9,180 tons of $\mathrm{U}_{3} \mathrm{O}_{8}$. Higher grades of thorium and 
other elements could be obtained by selective mining, as the distribution of the various elements within the massive carbonatite is erratic. The carbonatite exposed on this hill would all be in the category of reserves. Probable potential resources would lie below Iron Hill and could be extended to a depth of another $800 \mathrm{ft}$. The area underlain by carbonatite is $38,070,000 \mathrm{ft}^{2}$. Carbonatite classified as probable potential resources amounts to $2,672,000,000$ tons, which contains 114,900 tons of $\mathrm{ThO}_{2}, 1,523,000$ tons of $\mathrm{Nb}_{2} \mathrm{O}_{5}, 10,590,000$ tons of total rare earth oxides, and 33,930 tons of $\mathrm{U}_{3} \mathrm{O}_{8}$.

The reserves that form Iron Hill, itself, could be mined by removing the hill. The probable potential resources, which would be mined from an open pit, are less than the total resources because the walls of the pit must be terraced to an overall slope of approximately $45^{\circ}$. Therefore, if the carbonatite were to be mined to a depth of $800 \mathrm{ft}$ below the hill that was stripped away, then either some of the carbonatite must be left in the sides of the pit or the cost of mining must be increased by widening the pit and removing an everincreasing amount of country rock. The method chosen would depend on the price of both thorium and the other coproducts. In this paper, we have calculated the probable potential resources assuming that the open pit was made entirely within the carbonatite. The open pit would have an overall slope of 1:1 effectively eliminating about half the carbonatite on the flanks. Minable carbonatite in an open pit having a depth of $800 \mathrm{ft}$ would be $2,030,000,000$ tons. This amount of carbonatite would contain approximately 87,300 tons of $\mathrm{ThO}_{2}$ producible at less than $\$ 15 / \mathrm{lb}$ if niobium, uranium, and rare earths are recovered, but more than $\$ 50 / \mathrm{lb}$ if they are not. In addition, this carbonatite would also contain $1,160,000$ tons of $\mathrm{Nb}_{2} \mathrm{O}_{5}, 8,050,000$ tons of total rare-earth oxides, and 25,800 tons of $\mathrm{U}_{3} \mathrm{O}_{8}$.

As previously noted, the cost of producing $\mathrm{ThO}_{2}$ from this massive carbonatite is calculated two ways: (1) its cost if $\mathrm{ThO}_{2}$ is the sole product obtained from the carbonatite, and (2) its cost if $\mathrm{Nb}_{2} \mathrm{O}_{5}$, total rare-earth oxides, and $\mathrm{U}_{3} \mathrm{O}_{8}$ are all recovered in addition to the $\mathrm{ThO}_{2}$. The cost of producing $\mathrm{ThO}_{2}$ if it is the sole product redovered is $\$ 68 / \mathrm{lb}$. The value of the $\mathrm{Nb}_{2} \mathrm{O}_{5}$, total rare earth oxides, and $\mathrm{U}_{3} \mathrm{O}_{8}$ were obtained from recent price quotations. If a market could be obtained for all these metals at 1978 prices, they would pay for the cost of mining and milling. The value of these three products is more than twice that of $\mathrm{ThO}_{2}$ in the rock if the latter were to be sold for $\$ 50 / \mathrm{lb}$. Therefore, mining this body is dependent on a multi-element product with the production of $\mathrm{ThO}_{2}$ linked to the production of $\mathrm{Nb}_{2} \mathrm{O}_{5}$, total rare earth oxides, and $\mathrm{U}_{3} \mathrm{O}_{8}$.

\section{SULPHIDE QUEEN BODY, MOUNTAIN PASS, CALIF.}

The Mountain Pass district is in the northeastern corner of San Bernardino County, Calif. near the eastern edge of the Mojave Desert (fig. 1). The district is part of a rolling upland that lies several thousand feet above and to the west of Ivanpah Valley. The area is easily accessible, as the massive carbonatite lies only two-thirds of a mile north of U.S. Interstate Highway 15, which goes through Mountain Pass, about $170 \mathrm{mi}$ northeast of San Bernardino, Calif., and $60 \mathrm{mi}$ southwest of Las Vegas, Nev.

The massive carbonatite called the Sulphide Queen body is Precambrian in age and has intruded a well-foliated metamorphic complex. The metamorphic rocks also are intruded by several kinds of potassium-rich rocks, also of Precambrian age. The intrusives include biotite shonkinite, hornblende and biotite syenite, and granite (Olson and others, 1954, p. 5-10). The Precambrian rocks form an elongate block bounded on the east by the alluvium of Ivanpah Valley and on the west by Paleozoic and Mesozoic sedimentary and volcanic rocks. The Clark Mountain fault separates the Paleozoic and Mesozoic rocks from the Precambrian rocks (Olson and others, 1954, pl. 1). In addition to the main Sulphide Queen carbonatite, carbonatite dikes intrude the older Precambrian rocks; most of the carbonatite dikes lie in an area extending about $3,000 \mathrm{ft}$ northwest from the main carbonatite. The Sulphide Queen carbonatite, most of the carbonatite dikes, and the bulk of the alkalic igneous rocks occur in an area less than $1 \mathrm{mi}^{2}$. Thoriumbearing and rare-earth-bearing veins occur mainly to the southeast of this area. The thoriumbearing veins are discussed in the section on "Veins."

The Sulphide Queen massive carbonatite (fig. 6) is an irregularly shaped body elongate in a northsouth direction, having an overall length of 2,400 $\mathrm{ft}$ and an average width of about $400 \mathrm{ft}$ (Olson and others, 1954, p. 41). It varies considerably in 

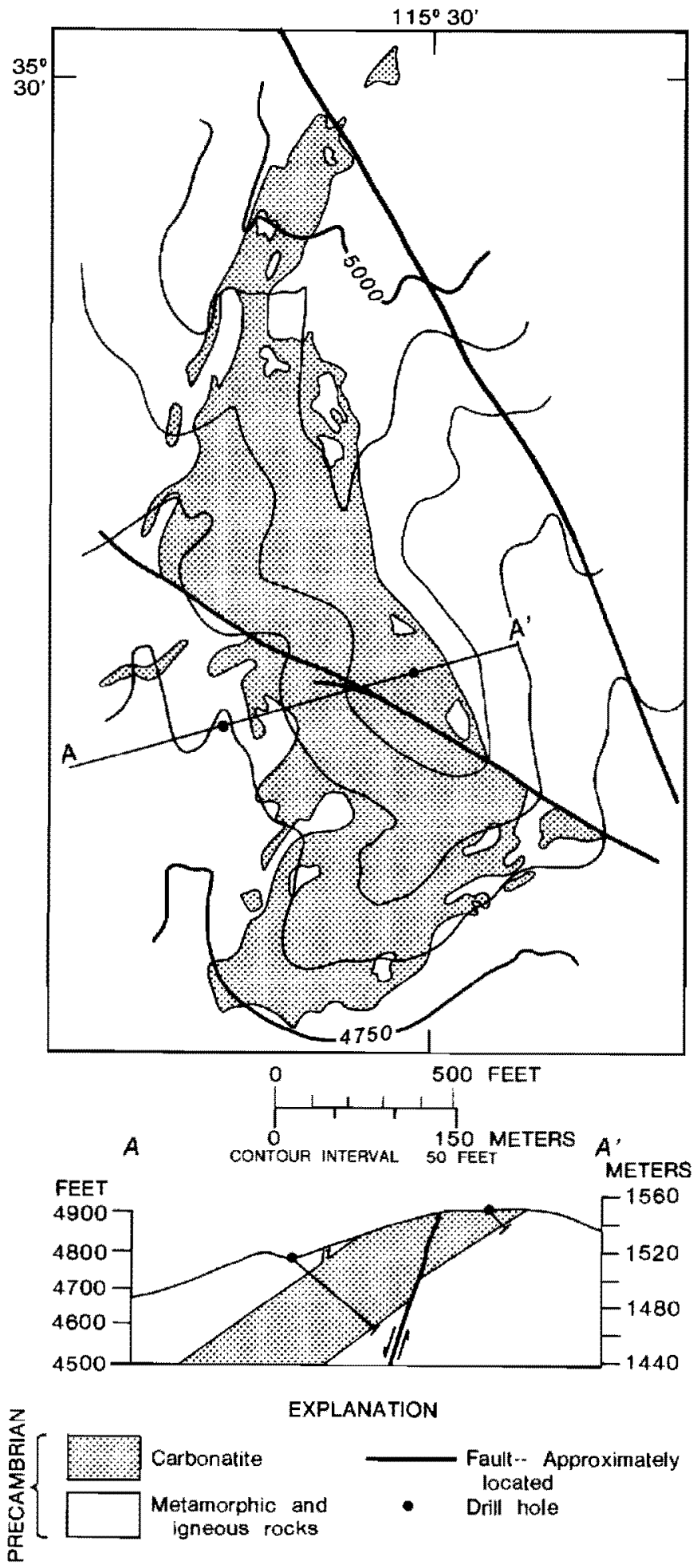

Figune 6.-Generalized geologic map and section of the original surface of the Sulphide Queen carbonatite body. Map simplified from Olson. Shawe, Pray, and Sharp (1954, p. 8); section from Evans (1966, p. 25).

width; its maximum width in the southern part is $700 \mathrm{ft}$, but in the northern part is less than $100 \mathrm{ft}$. It varies in thickness from $160 \mathrm{ft}$ on the north to $250 \mathrm{ft}$ on the south. Apophyses of carbonatite ex- tend from this body into the enclosing gneiss, and inclusions of gneiss and various igneous rocks as much as $150 \mathrm{ft}$ long are found in the carbonatite. The carbonatite body dips $33^{\circ}$ to $40^{\circ}$ to the west (fig. 6) (Evans, 1966, p. 29).

The massive carbonatite varies in composition from place to place. Some of these composition changes are large enough to define and Olson, Shawe, Pray, and Sharp (1954, pl. 8, p. 42-47) outlined and described three separate rock types within the massive carbonatite, gray calcitebarite rock, ferruginous dolomitic rock, and silicified carbonate rock. Local variations in composition are observed within these three rock types. The most common rock type is gray calcite-barite rock that contains 40 to 70 percent calcite, 15 to 50 percent barite, and 5 to 15 percent bastnaesite. Chlorite, crocidolite, and phlogopite commonly occur in this rock. Other minerals present locally in small quantities include quartz, biotite, apatite, thorite, allanite, goethite, hematite, zircon, galena, magnetite, pyrite, and leucoxene (Olson and others, 1954, p. 43). Fine-grained ferruginous dolomitic carbonatite occurs in small bodies in the northern and southwestern parts of the main body. This rock can be distinguished from the calcite-barite carbonatite by its reddish or grayish-brown color on weathered surfaces. The principal carbonate mineral in this second type is dolomite. Like the gray calcite-barite rock, this second type also contains bastnaesite and barite. In addition, monazite is common in many places, and parisite, $(\mathrm{Ce}, \mathrm{La})_{2} \mathrm{Ca}\left(\mathrm{CO}_{3}\right)_{3} \mathrm{~F}_{2}$, and sahamalite, $(\mathrm{Mg}, \mathrm{Fe}) \mathrm{Ce}_{2}\left(\mathrm{CO}_{3}\right)_{4}$, also have been noted in a few places. Silicified carbonate rock is found principally along faults and shear zones in the calcitebarite carbonatite. This type is a hard resistant rock in which quartz is much more common and calcite much less common than in the more widespread gray calcite-barite carbonatite. The silicified carbonatite is made up principally of quartz, barite, and bastnaesite, with small amounts of calcite, hematite, goethite, sericite, and galena.

The Sulphide Queen carbonatite was sampled by D. R. Shawe and J. C. Olson during their study of this district in the early 1950's (Olson and others, 1954; Shawe, 1953). Sample data on this deposit come from this early work. Samples of the carbonatite, which did not contain any visible concentrations of thorium-bearing minerals, con- 
tained from 0.01 to 0.09 percent $\mathrm{ThO}_{2}$. Five small areas containing monazite yielded 0.08 to 0.2 percent $\mathrm{ThO}_{2}$. The overall average of the massive carbonatite was calculated to be 0.026 percent $\mathrm{ThO}_{2}$. Uranium was chemically analyzed in only a few samples, and in these it ranged from 0.001 to 0.007 percent. Little accurate data are available on the thorium-to-uranium ratios, but if these ratios are similar to those of the carbonatite dikes that occur just north of the massive carbonatite, then they are from about 10 to 80 . The Sulphide Queen carbonatite is extremely rich in rare earths. Olson, Shawe, Pray, and Sharp (1954, p. 68) gave the total rare-earth-oxide content of 59 samples. These range from zero to 38.92 percent. Only eight of these samples contained less than 1 percent total rare-earth oxides, and the average of these 59 samples is 6.9 percent.

The Sulphide Queen carbonatite is one of the world's large resources of rare earths. This carbonatite, which was discovered by the U.S. Geological Survey in August 1950 (Evans, 1966, p. 23), has been mined by open-pit methods by the Molybdenum Corp. of America since the early 1950's. A mill has been constructed on the site within a few hundred yards of the ore body. The mill not only separates bastnaesite but also several types of rare-earth products. Recovery of thorium from this deposit normally would be as a byproduct of the rare-earth mining.

Reserves in the Sulphide Queen carbonatite body were projected down dip for a distance of $500 \mathrm{ft}$. This mass of rock has $36,800,000$ tons of carbonatite that contains approximately 9,750 tons of $\mathrm{ThO}_{2}$ and 2,540,000 tons of total rareearth oxides. Probable potential resources would be projected another $500 \mathrm{ft}$ down dip and would contain an equal amount of $\mathrm{ThO}_{z}$, and total rareearth oxides. The only cost that normally would be charged to thorium would be that of adding an extra circuit to an already operating mill to separate $\mathrm{ThO}_{2}$. The capital and operating costs of this circuit would be considerably less than $\$ 15 / \mathrm{lb}$ of produced $\mathrm{ThO}_{2}$. Therefore, all the reserves and probable potential resources of $\mathrm{ThO}_{2}$ produced as a byproduct of rare earths would fall in the less than $\$ 30 /$ lb category. If the entire cost of operating this property was paid by selling $\mathrm{ThO}_{2}$, then the price of $\mathrm{ThO}_{2}$ would be between $\$ 30$ and $\$ 80 / \mathrm{lb}$. Costs of mining would be greater as the pit is deepened, because the carbonatite body dips moderately to the west under increasing amounts of country rock which would have to be removed. Other factors that may either slow down or stop this operation include a drop in the demand for rare earths, development of a market by a larger and cheaper source of rare earths such as could be developed at the Elliot Lake uranium deposits in Ontario, Canada, and various management aspects.

\section{NORTH AND SOUTH GAROLINA PLACER DEPOSITS}

Monazite-bearing stream placers in the North and South Carolina Piedmont were the world's first source of thorium, with production starting in 1887 (Olson and Overstreet, 1964, p. 3). These placers, which were mined in the years 1887-1911 and 1915-1917, are at the headwaters of streams that drained the monazite-bearing crystalline rocks (Mertie, 1975, p. 7). Total production during this period amounted to 5,483 tons of monazite (Overstreet and others, 1968, p. 2). Mining ceased in 1917 because the cost of producing Carolina monazite was greater than that of monazite produced from beach placers in India and Brazil and not because the reserves were depleted. Most early mining in the Carolina Piedmont was by sluicing, which was done mainly by groups of one to three men. Few of these deposits were worked to depths in excess of 3 to $4 \mathrm{ft}$ (Mertie, 1975, p. 8). Five geologic factors controlled the location of these early placers: (1) relation of stream to monazite-bearing rock, (2) thickness of monazitebearing sediment, (3) thickness of overburden, (4) flow of water in stream, and (5) height of water table in flood plain (Overstreet and others, 1968, p. 8-9). These factors tended to restrict mining to headwaters areas where stream channels are small and flood plains are narrow. Sufficient water for sluicing generally was present in the upper parts of most of the small streams, but too great a flow of water, as commonly occurred downstream, prevented mining there. The small placers commonly were formed in a period of only a few years, as the headwater stretches of many streams were mined repeatedly during a period of $20 \mathrm{yr}$.

The source of the monazite, as well as the location of many of the placers, is in a northeasttrending belt of rocks that stretches for $600 \mathrm{mi}$ from Virginia to Georgia (Mertie, 1953, p. 15). Most of the placers, and those of highest grade, 
lie in the Piedmont of North and South Carolina (figs. 1 and 7). This area from north to south lies within parts of the following drainage basins: (1) Catawba, (2) Broad, (3) Pacolet, (4) Tyger, (5) Enoree, (6) Saluda, and (7) Savannah Rivers. The area is underlain by high-grade metamorphic rocks intruded by quartz monzonite and pegmatite. Some of the quartz monzonite and pegmatite bodies contain monazite; others are free of monazite. Overstreet (1967, p. 184-189) noted that most of the monazite is derived from such high-grade metamorphic rocks as sillimanite schist. He believed that the monazite formed from constituents in the original shales or sandstones, and that monazite is more abundant and is richer in $\mathrm{ThO}_{2}$ in metamorphic rocks of higher grade facies than those of lower grade facies. Although monazite is best known from the placers in the Piedmont, it and other heavy minerals have been carried eastward from there down various rivers. All formations in the Coastal Plain probably received varying amounts of heavy minerals. In particular, the Tuscaloosa Formation of Late Cretaceous age has received a widely dispersed but significant amount of monazite (Mertie, 1975, p. 12). The Tuscaloosa directly overlaps the crystalline rocks of the Piedmont, and along its old shoreline, this formation might be expected to have a higher tenor of the heavy minerals than other formations of the Coastal Plain. The Fall Line, shown on figure 7, extending across South Carolina, is a sharp topographic break caused by differential erosion between the hard crystalline rocks of the Piedmont and the soft sedimentary rocks of the Coastal Plain. The Tuscaloosa Formation crops out just southeast of this line. Streams cutting this area have reworked the sand from the Tuscaloosa Formation and, in places, have formed heavy-mineral placers containing monazite. This area has not been nearly as well explored as the Piedmont, but Williams (1967, p. 17-20, 25) reported heavy-mineral concentrations at 28 localities. The best known of these is Horse Creek, southwest of Aiken (fig. 7), which was the site of the first large-scale mining of stream placers for monazite and other heavy minerals in the Carolinas. The alluvium here was mined by dredge by Marine Minerals, a Division of Heavy Mineral Co., between June 1955 and July 1958 (Williams, 1967, p. 25). This company recovered monazite, ilmenite, rutile, zircon, and staurolite.
The heavy-mineral content of these sediments was about 1 to 1.5 percent, of which monazite made up about 8 percent of the total (Mertie, 1975 , p. 27). Sand and gravel also were sold. This deposit was reported to contain about $10,000,000$ $\mathrm{yd}^{3}$ (cubic yards) of alluvium of which approximately 4,000,000 $\mathrm{yd}^{3}$ were mined during the dredging operation (Williams, 1967, p. 25). Although the actual output of the Horse Creek placer has not been released, Overstreet (1967, p. 260), by comparing it with a nearby placer, estimated that it may have yielded about $1,200-1,500$ tons of monazite per year.

The stream sediments containing the monazite placers in the Piedmont are remarkably similar from the Catawba River on the north to the Savannah River on the south. They were deposited on deeply weathered flat-floored valleys. They are generally well bedded, poorly graded, unconsolidated, and occur in successive layers of differing lithology (Overstreet and others, 1959, p. 712). The lowermost unit commonly is a quartz pebble gravel with a sandy clay matrix. Overlying the gravel, or where it is missing, lying directly on bedrock, is a bed of dense gray clay. Above the clay is fine-grained to coarse-grained gray to buff sand that is overlain by clayey silt. The uppermost unit is red to brown sandy silt. Average thickness of the sediments is $14.6 \mathrm{ft}$. The layer of gravel at the bottom of the deposit averages $1.5 \mathrm{ft}$ thick, the layer of clay about $3.6 \mathrm{ft}$, and the sand and silt about $9.5 \mathrm{ft}$ thick. Monazite generally is found in all units, but commonly is most abundant in the gravel at the bottom of the deposit and least abundant in the clay.

Heavy mineral concentrations are greatest near the headwaters of the streams. Here, where the streams start and the placer deposits are shallow, narrow, and short, is where mining was carried out at the turn of the century. Progressing downstream, the streams have more water and the placers commonly are deeper, wider, and longer. Unfortunately, the grade of the heavy minerals, including monazite, decreases as the distance fthe source increases. Placers, in order to be operated by modern methods, must be close enough to the source so that the grade of monazite is not too low but far enough downstreram so that the volume of sediment is large enough to pay for the cost of mechanically mining the placer. These conditions most likely are to be found in two areas along the streams in 


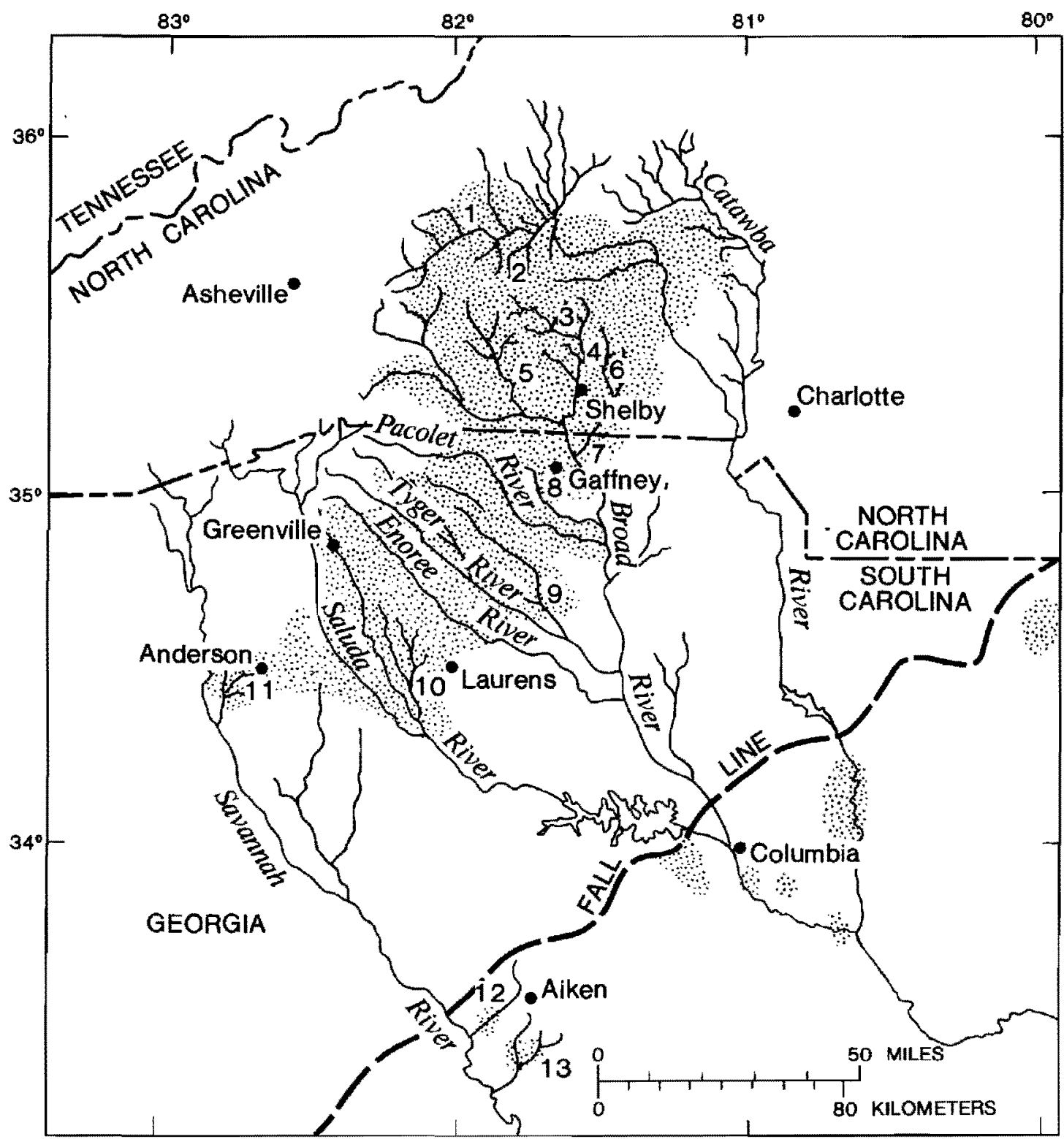

\section{EXPLANATION}

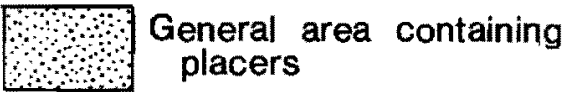

Placers mentioned in text

1 South Muddy Creek

2 Silver Creek

3 First Broad River and its tributaries-Hinton Creek, Duncans Creek, and Wards Creek

4 Knob Creek

5 Sandy Run Creek
6 Buffalo Creek

7 Broad River at its junction with Buffalo Creek

8 Thicketty Creek

9 North Tyger River at its junction with Middle Tyger River

10 North and South Rabon Creeks

11 Big Generostee Creek

12 Horse Creek

13 Hollow Creek

Figure 7.-Known stream-placer areas in North and South Carolina. Compiled principally from maps by Overstreet, Theobald, and Whitlow (1959, fig. 1) and Williams (1967, fig. 1). 
the Carolinas: (1) adjacent to, but not in, the headwaters of monazite-bearing streams in the Piedmont, and (2) just below the Fall line on the Tuscaloosa Formation where a second generation of placers have formed from reworked sandstone.

The heavy-mineral content of the placers is fairly low, and ranges from about 0.15 to 2.0 percent, or 4.1 to $54 \mathrm{lb}$ of heavy minerals per cubic yard of alluvium. Monazite makes up from 3.5 to 13 percent of the heavy minerals. The proportions of various other heavy minerals vary widely between individual placers. Ilmenite and garnet are the commonest heavy minerals in the Piedmont placers, with the former making up from 20 to 70 percent of the total and the latter from 2 to 50 percent. Rutile may make up from 0.3 to 7 percent of the heavy minerals and zircon from practically nothing to 14 percent. Sillimanite and kyanite together range from trace amounts to about 20 percent. Epidote is important in a few placers. Magnetite and xenotime commonly are found in minor amounts. Other heavy minerals that are present in some placers include tourmaline, sphene, staurolite, andalusite, and a black radioactive mineral.

The heavy mineral distribution at the two deposits east of the Fall Line for which information is available shows several differences from that in the Piedmont. The largest difference is in the increase in staurolite, which here makes up 7 and 38 percent of the two deposits (Mertie, 1975, p. 27; Kline and others, 1954, p. 27). Rutile and zircon also make up a greater proportion of the heavy minerals here than in the Piedmont, with zircon reported at 19 and 11 percent and rutile at 15 and 10 percent of the heavy minerals. Monazite concentrations for the two areas are similar to those found in part of the Piedmont. The differences in heavy mineral content of the two areas is due to varied sources of sediment in the Tuscaloosa Formation.

The monazite in the alluvium has been sampled in many placer in the North and South Carolina Piedmont. These samples not only were taken in each placer on each stream, but also were divided into type of material sampled (gravel, sand and silt, or clay). Average grades were obtained for each stream, and these figures were compiled for all streams within the Piedmont that belong to the Catawba, Broad, Pacolet, Tyger, Enoree, Saluda, and Savannah River basins. Summaries of this detailed sampling program are reported by
Overstreet, Theobald, and Whitlow (1959, p. 710-711). Overall variations in tenor were similar in the various river basins. The clay layers in the various streams contained from 0.01 to 0.6 $\mathrm{lb} / \mathrm{yd}^{3}$ (pounds per cubic yard) of monazite. Average grade of clay samples in each of the seven river basins ranged from 0.1 to $0.3 \mathrm{lb} / \mathrm{yd}^{3}$. The sand and silt in the individual streams had from 0.2 to $2.4 \mathrm{lb} / \mathrm{yd}^{3}$ of monazite. The average grade of sand and silt samples from each of the seven basins varied from 0.5 to $1.3 \mathrm{lb} / \mathrm{yd}^{3}$. The gravel in the various streams had an average yield of from 0.2 to $4.1 \mathrm{lb} / \mathrm{yd}^{3}$ of monazite. Average grade of the gravel samples from the seven river basins was from 1.0 to $2.4 \mathrm{lb} / \mathrm{yd}^{3}$. The overall weighted average of all the sediments in each river basin ranged from 0.4 to $1.0 \mathrm{lb} / \mathrm{yd}^{3}$ of monazite, for an average monazite content of 0.015 to 0.037 percent of the alluvium.

The monazite content of the alluvium east of the Fall Line is less well known, but the average grade of 19 individual placers tabulated by Williams $\left(1967\right.$, p. 6) ranged from 0.1 to $2.7 \mathrm{lb} / \mathrm{yd}^{3}$ of monazite, a monazite content of 0.0037 to 0.10 percent of the alluvium.

Monazite is principally a rare earth mineral, commonly containing 60 to 63 percent total rareearth oxides. The $\mathrm{ThO}_{2}$ content can be highly variable, but the range is small for the alluvial monazite of the Carolinas. The $\mathrm{ThO}_{2}$ content of 52 samples of alluvial monazite from the Carolinas ranges from 2.5 to 7.8 percent and the mean is 5.67 percent (Mertie, 1975, p. 7). The average $\mathrm{ThO}_{2}$ content of the seven river basins in the Piedmont ranges from 4.21 to 5.96 percent (Overstreet and others, 1959, p. 712). A sample of alluvial monazite from Hollow Creek, the largest known placer east of the Fall Line, contains 5.08 percent $\mathrm{ThO}_{2}$ (Kline and others, 1954, p. 26.)

Monazite also contains a small amount of uranium, and the $\mathrm{U}_{3} \mathrm{O}_{8}$ content of 52 samples of alluvial monazite from the Carolinas ranges from 0.18 to 0.98 percent (Mertie, 1975, p. 7). Average $\mathrm{U}_{3} \mathrm{O}_{8}$ content of the seven river basins in the Piedmont ranges from 0.39 to 0.70 percent (Overstreet and others, 1959, p. 712). A sample of monazite from Hollow Creek yielded 0.54 percent $\mathrm{U}_{3} \mathrm{O}_{8}$ (Kline and others, 1954, p. 26).

Two types of resources have been calculated for the placer deposits: reserves and probable potential resources. The reserves are in 16 of the larger placers, which have been sampled both at the sur- 
face and at depth by at least one line of drill holes. Drilling on these placers was done with a churn drill by the U.S. Bureau of Mines between 1951 and 1954 (Marshall, 1956, p. 30-31). A field laboratory was established at Shelby, N.C. where the amount of monazite and various other heavy minerals was determined. These placers were discussed in nine reports, eight of which were prepared jointly by the U.S. Bureau of Mines and the U.S. Geological Survey. Nine of these placers are in the Piedmont of North Carolina on: (1) Silver Creek in Burke County (Hanson and White, 1954), (2) South Muddy Creek in McDowell County (Hansen and White, 1954), (3) Sandy Run Creek in Rutherford County (Griffith and Overstreet, 1953a), (4) Buffalo Creek in Cleveland and Lincoln Counties (Griffith and Overstreet, 1953b), (5) Knob Creek in Cleveland County (Griffith and Overstreet 1953c), (6) First Broad River in Cleveland County (Hansen and Cuppels, 1954), (7) Hinton Creek in Cleveland County (Hansen and Cuppels, 1954), (8) Duncans Creek in Cleveland County (Hansen and Cuppels, 1954), and (9) Wards Creek in Cleveland County (Hansen and Cuppels, 1954) (fig. 7). Six of these placers are in the Piedmont of South Carolina. They are on: (1) Big Generostee Creek in Anderson County (Hansen and Caldwell, 1955), (2) North Rabon creek in Laurens County (Hansen and Caldwell, 1955), (3) South Rabon Creek in Laurens County (Hansen and Caldwell, 1955), (4) North Tyger River at its junction with the Middle Tyger River in Spartanburg County (Hansen and Cuppels, 1955), (5) Thicketty Creek in Cherokee County (Hansen and Theobald, 1955), and (6) Broad River at its junction with Buffalo Creek in Cherokee County (Hansen and Theobald, 1955). Another of these placers, just east of the Fall Line in South Carolina, is on Hollow Creek in Aiken County (Kline and others, 1954). In addition, reserves in South Carolina have been summarized by Williams (1967). The reserves in the Carolinas, which are in 15 placers in the Piedmont and one placer east of the Fall Line, contain 5,270 tons of $\mathrm{ThO}_{2}$. This $\mathrm{ThO}_{2}$ would come from 99,500 tons of monazite, which also would contain 507 tons of $\mathrm{U}_{3} \mathrm{O}_{8}$ and 62,300 tons of total rare-earth oxides. In addition to the monazite, amounts of other economically valuable minerals would include 668,000 tons of ilmenite, 84,100 tons of rutile, and 147,000 tons of zircon.

The probable potential resources that were summarized by Overstreet, Theobald, and Whitlow (1959, p. 713-714), were appraised by reconnaissance methods. The margins of individual flood plains were outlined stereoscopically on aerial photographs, which then were compiled into mosaics. After a field check as to accuracy of these measurements, the areas of the flood plains were outlined by polar planimeter. Accuracy of the planimetry was within 5 percent on an area having $200,000 \mathrm{yd}^{2}$ (square yards) and 1 percent on an area exceeding $1,000,000 \mathrm{yd}^{2}$. Average depth of alluvium in each flood plain was estimated from stratigraphic measurements of exposed sediments and from holes made with a vehicle-mounted auger. The amount of monazite and other heavy minerals in the sediment was estimated from microscopic study of heavy minerals panned from several thousand samples. The panned concentrates were divided into three to five size fractions. A split of 100 to 150 grains was taken from each size fraction. These grains were identified and counted. Numerical frequencies of each mineral were converted to weight percent by multiplying by the appropriate specific gravity.

The summary of thorium resources by Overstreet, Theobald, and Whitlow (1959), is based on more detailed studies made by them and others of the U.S. Geological Survey monazite project. The most important areal studies were of the following drainage basins: (1) Savannah and Saluda Rivers (Caldwell and White, 1973), (2) Enoree, Tyger, and Pacolet Rivers (Cuppels and White, 1973), (3) Broad River (Theobald, 1962), and (4) Catawba River (White, 1962). Data on amounts of heavy minerals in many stream placers in the southeastern United States also are summarized by Overstreet and others (1968). The thorium, rare-earth, and uranium contents of monazite in the Carolinas were obtained mainly from Overstreet $(1967$, p. $180-228,231-262)$, who has compiled most of the available analyses of this mineral. The probable potential resources of the Carolinas total 36,800 tons of $\mathrm{ThO}_{2}$. This $\mathrm{ThO}_{2}$ comes from 725,000 tons of monazite, which also contains 3,210 tons of $\mathrm{U}_{3} \mathrm{O}_{8}$ and 441,000 tons of total rare-earth oxides. In addition, 318,000 tons of zircon are estimated in these deposits. Data are not available on the amounts of ilmenite and rutile present.

Cost studies also were made on placer sands by the U.S. Bureau of Mines personnel. Cost calcula- 
tions made by operators of monazite placers go only as far as the separation of the individual heavy mineral. We have carried this one step further and have included the separation of the $\mathrm{ThO}_{2}$ from the monazite in order to have a basis for comparing the cost of $\mathrm{ThO}_{2}$ between different types of deposits. The cost calculation covers the mining of the sand and its processing through three separate mills. In the first mill, the heavy minerals would be separated from the stream alluvium; in the second, monazite and various other heavy minerals would be separated from each other; and in the third, thorium, uranium, and rare earths would be recovered from the monazite.

Mining would be done by dredge. Thus, the first step would be to make a pond using a drag line into which to put the dredge and an adjacent floating mill. A hydraulic dredge having a rotating cutter head would be used. The rotating cutter head would loosen the alluvium, and the sediment would be pumped to the surface. From there it would be pumped through a pipe line, floating on pontoons, to a floating heavy-mineral mill. Not all placers contain enough sediment to support operation of a dredge and a mill. The minimum capacity for a gravity mill was assumed to be $1,000 \mathrm{yd}^{3}$ of material per day; the minimum mill life would be 5 yrs. Therefore, a placer containing less material than would feed a mill at this rate for $5 \mathrm{yr}, 1,750,000 \mathrm{yd}^{3}$, was not considered in the cost calculations.

The mining costs are divided into capital and operating costs. Capital costs include mine development, mining plant, and equipment. These costs do not include those for exploration, acquisition of land, or for obtaining working capital, because these costs have not been considered in comparative cost calculations for uranium. Most development costs include clearing trees and brush from the placer, building roads, and digging the initial pond with the dragline. Mining-plant costs include the dredge and any buildings needed for the operation. Equipment costs include all equipment and supplies necessary to bring the property into production. Operating costs are divided into direct, indirect, and fixed costs. Direct costs apply directly to the dredging operation and include labor, supervision, power and fuel consumption, cutter bits, and supplies. The indirect costs are for administrative and clerical help, facility supplies, and general overhead. Fixed costs are for local taxes and insurance. These costs are a function of the capital costs and are estimated to be 3 percent of capital costs.

Milling of placer sands is a fairly well-known process. In the first mill, which is attached to the dredge, the various heavy minerals are separated from the rest of the alluvium. This separation can be made on jigs, as has been done on many small placer operations, or with spiral gravity separators, the process used on the beach sands in Florida and Georgia. We selected the spiral separator, as it fits our overall mill plan better. The heavy sands go through three series of spirals-roughers, cleaners, and finishers-and the finished product is dewatered. The heavy concentrate makes up only about 0.1 to 1.5 percent of the alluvium mined. The rest of the alluvium is returned to the end of the pond through a moving pipe that spreads it evenly into the valley bottom so that it can quickly be returned to its original agricultural use. The heavy sands are then trucked to a district heavy mineral separating plant. There, magnetic and electrostatic separators separate monazite from the heavy sands. In addition, where present in sufficient amounts, ilmenite, rutile, and zircon also are recovered.

$\mathrm{ThO}_{2}$ is extracted form the monazite in a leachsolvent plant. The amount of monazite form each placer makes up from about 1 to 14 percent of the total heavy sands, so the monazite form several magnetic and electrostatic mills can supply a smaller leach-solvent plant. This plant extracts not only the thorium from monazite, but also recovers uranium and rare earths.

The milling-cost calculations are complicated because material from each placer goes to three mills. The cost of building and operating a spiral gravity mill is paid for from the minerals recovered from one or possibly two placers, but the costs for a magnetic-electrostatic mill will be proportioned among a number of placers, and the cost for a leach-solvent plant will be proportioned among many placers. In other words, that part of the capital and operating costs of a particular mill that are paid for from the receipts of a particular placer is directly proportional to the ratio of the amount of material received from that placer to the total material processed.

The milling costs for each mill are divided into capital and operating costs. Capital costs for each mill consist of the cost of building each mill and 
the cost of the equipment that is necessary to make it operational. The size of the mill is the principal factor that affects the original cost of the mill. The proposed gravity mill can be designed to handle from 1,000 to 22,000 tons of sediments per day for an operating life of at least $5 \mathrm{yr}$. The magnetic-electrostatic mill proposed is designed to handle from 10 to 1,200 tons of heavy concentrates per day. The life of this type of mill, assuming the most efficient use of all the equipment, would be at least $15 \mathrm{yr}$. The leach-solvent mill is a much smaller plant, and the proposed design can be used for a plant having an imput of from 1 to 50 tons of monazite per day. This plant also is most efficient if it has a life of at least $15 \mathrm{yr}$.

The operating costs for milling can be divided into direct, indirect, and fixed costs. The direct costs include fuel and power consumption, reagents, labor, supervision, and supply maintenance. The indirect costs are those for administration, technical and clerical help, facility maintenance, office supplies, and general overhead. Fixed costs are for local taxes and insurance on the milling facilities. The principal variable in a mill's operating cost is its capacity.

Cost calculations were made on 16 of the largest and best known deposits in the Piedmont and on the Hollow Creek deposit east of the Fall Line. These were the only deposits for which sufficient data were available to make a complete cost calculation. Enough data are present, however, on most of the other Piedmont deposits so that a general cost range can be estimated by comparing the size and grade of these deposits to those where more complete data are available.

The cost calculations indicate that only the deposit on Hollow Creek east of the Fall Line (fig. 7) can produce $\mathrm{ThO}_{2}$ at less than $\$ 30 / \mathrm{lb}$. This property has reserves of 2,040 tons of $\mathrm{ThO}_{2}$ and 216 tons of $\mathrm{U}_{3} \mathrm{O}_{8}$ in 40,100 tons of monazite (Kline and others 1954, p. 26$)$. The monazite also contains approximately 25,500 tons of total rare-earth oxides. In addition, this deposit would yield 66,100 tons of zircon, 55,400 tons of rutile, and 160,000 tons of ilmenite. Although these byproducts would normally be recovered during the mining and milling of the Hollow Creek placer, the cost here of producing $\mathrm{ThO}_{2}$ without any byproducts would still be less than $\$ 30 / \mathrm{lb}$.

None of the Piedmont placers could be operated at less than $\$ 50 / \mathrm{lb}$ of $\mathrm{ThO}_{2}$, although the placer on Knob Creek was within a few dollars of this figure. The reasons that the placer at Hollow Creek can be operated at a much lower cost than any of the Piedmont placers are: (1) its large size-it is about twice as large as the largest Piedmont placer, (2) it has a high monazite content, and (3) it contains more zircon and rutile than any of the Piedmont placers.

\section{BEACH PLACER DEPOSITS IN FLORIDA AND GEORGIA}

Beach placers, as a source of thorium, present a paradoxical problem. On the one hand, for at least $20 \mathrm{yr}$ they have been the only place thorium has been mined in the United States, yet few deposits contain thorium at as low a grade as do beach placers. For example, the concentration of thorium in a beach placer commonly is only $1 / 250$ as much as that in a vein deposit. The $\mathrm{ThO}_{2}$ content of beach placers in the United States from which this oxide has been recovered commonly ranges from 8 to $20 \mathrm{ppm}$. How can thorium be produced from such low-grade ore? The answer is twofold: (1) beach placers are extremely cheap to process compared to most other deposits, and (2) the thorium is a byproduct, and its presence has little to do with the overall success of the operation. Beach placers may occur either along modern beaches or inland along older beaches where they formed during Pleistocene time. In either place they can be mined by open-pit methods, and even the older sands rarely have more than $15 \mathrm{ft}$ of overburden. As the groundwater level is high in Georgia and Florida, pits dug inland on the Pleistocene sands fill with water. These deposits are efficiently and economically mined by a dredge floating on these ponds. Sands have the advantage over hard-rock deposits not only in ease of mining but also in milling, as the material is not only already broken up but also sized. Sands are pumped from a dredge into a wet heavy-mineral concentrator, such as a Humphrey spiral, and the 4 percent or so of heavy minerals is separated from the lighter minerals. The heavy minerals are dried and divided into various mineral products by electromagnetic and electrostatic separators.

Beach placers in the eastern United States are mined principally for their $\mathrm{TiO}_{2}$ content. $\mathrm{TiO}_{2}$ is used in making the white pigment in paints, and 
many of the companies mining beach placers are at least in part controlled by paint companies. Titanium occurs in beach sand, principally as partly altered ilmenite; leucoxene and rutile may also be present. $\mathrm{TiO}_{2}$ makes up a large part of the heavy minerals in beach placers, and it commonly makes up from 1.1 to 2.0 percent of sands that contain 4 percent heavy minerals. Other mineral products that are marketed form some deposits include zircon, garnet, staurolite, kyanite, sillimanite, and monazite. Zircon, although not as common as the titanium minerals, is an important economic product, and during the latter part of 1977 was selling for $\$ 150$ per ton (Engineering and Mining Journal, 1977, p. 54). The types of marketable minerals vary from placer to placer. Monazite is a relatively unimportant byproduct in all of them, as it makes up from about 0.3 to 1 percent of the heavy mineral concentrates in deposits where it has been recovered; it was not reported in some beach placers. Monazite from beach placers contains about 50 percent total rare earths (Kremers, 1958, p. 2) and about 5 percent $\mathrm{ThO}_{2}$ (Calver, 1957, p. 25). At present, monazite is sold for its rareearth content and thorium is a byproduct. In short, thorium is a byproduct of rare earths in monazite, which is a minor byproduct of titanium mining. Increases in the amount of thorium produced from beach placers will most likely be due to greater demand for titanium, although a sharp increase in the price of zircon might also affect somewhat the rate of production. Thus, the amount of thorium produced from beach placers in the next $10 \mathrm{yr}$ will continue to be relatively steady and little affected by rises in the price of thorium. Production also may fluctuate with shutdowns for equipment repair or the opening of new deposits. An overall estimate of the amount of $\mathrm{ThO}_{2}$ that will be produced for the next $10 \mathrm{yr}$ from this source is 250 to 350 tons.

\section{REFERENCES CITED}

Adams, J. A. S., Kline, M. C., Richardson, K. A., and Rogers, J. J.W., 1962, The Conway Granite of New Hampshire as a major low-grade thorium resource: National Academy of Science Proceedings, v. 48, no. 11, p. 1898-1905.

Armbrustmacher, T. J., 1979, Thorium-, niobium-, and rareearth-bearing carbonatites from the Wet Mountains area, Fremont and Custer Counties, Colorado: Economic Geology, (in press).
Austin, S. R., 1968, Thorium, yttrium, and rare-earth analyses, Lemhi Pass-Idaho and Montana: U.S. Atomic Energy Commission Technical Memorandum issued by U.S. Atomic Energy Commission Technical Information Service Extension, Oak Ridge, Tenn., AEC-RID-2, 12 p.

Baxter, J. W., and Desborough, G. A., 1965, Areal geology of the Illinois fluorspar district, $\mathrm{Pt}$ 2-Karbers Ridge and Rosiclare quadrangles: Illinois Geological Survey Circular $385,40 \mathrm{p}$.

Baxter, J. W., Desborough, G. A., and Shaw, C. W., 1967, Areal geology of the Illinois fluorspar district, $\mathrm{Pt}$ 3-Herod and Shelterville quadrangles: Illinois Geological Survey Circular 413,41 p.

Brookins, D. G., Treves, S. B., and Bolivar, S. L., 1975, Elk Creek, Nebraska, carbonatite: strontium geochemistry: Earth and Planetary Science Letters, v. 28, p. 79-82.

Brown, J. S., Emery, J. A., and Myer, P. A., Jr., 1954, Explosion pipe in test well on Hicks dome, Hardin County, Illinois: Economic Geology, v. 49, no. 8, p. 891-902.

Caldwell, D. W., and White, A. M., 1973, Fluvial monazite deposits in the drainage basins of the Savannah and Saluda Rivers, South Carolina: South Carolina Division of Geology, Mineral Resources Series No. 2, 75 p.

Calver, J. L., 1957, Mining and mineral resources: Florida Geological Survey Bulletin 39, 132 p.

Carbonneau, C., and Caron, J. C. 1965 , The production of pyrochlore concentrates at St. Lawrence Columbium and Metals Corp.: Canadian Institute of Mining and Metallurgy Transactions, v. 68, p. 71-79.

Cuppels, N. P., and White, A. M.. 1973, Fluvial monazite deposits in the drainage basins of the Enoree, Tyger, and Pacolet Rivers, South Carolina: South Carolina Division of Geology, Mineral Resources Series No. 1, 74 p.

Engineering and Mining Journal, 1977, E/MJ Markets: Engineering and Mining Journal, v. 178, no. 12, p. 49-56.

Erickson, R. L. and Blade, L. V., 1963, Geochemistry and petrology of the alkalic igneous complex Magnet Cove, Arkansas: U.S. Geological Survey Professional Paper $425,95 \mathrm{p}$.

Evans, J. R., 1966, California's Mountain Pass mine now producing europium oxide: California Division of Mines and Geology Mineral Information Service, v. 18[19], no. 2, p. 23-32.

Griffith, R. F., and Overstreet, W. C., 1953a, Sandy Run Creek monazite placer, Rutherford County, North Carolina: U.S. Atomic Energy Commission Report RME-3114, 27 p.

1953b, Buffalo Creek monazite placer, Cleveland and Lincoln Counties, North Carolina: U.S. Atomic Energy Commission RME-3113, 17 p.

1953c, Knob Creek monazite placer, Cleveland County, North Carolina: U.S. Atomic Energy Commission Report RME $-3112,30$ p.

Hansen, L. A., and Caldwell, D. W., 1955, Monazite placers on Rabon Creek, Laurens County, and Big Generostee Creek, Anderson County, South Carolina: U.S. Atomic Energy Commission Report RME-3118, 25 p.

Hansen, L. A., and Cuppels, N. P., 1954, Monazite placer on the First Broad River and its tributaries, Cleveland County, North Carolina: U.S. Atomic Energy Commission Report RME-3116, 27 p. 
1955, Monazite placer at the junction of the North Tyger River with the Middle Tyger River, Spartanburg County, South Carolina: U.S. Atomic Energy Commission Report RME-3117, 23 p.

Hansen, L. A., and Theobald, P. K., Jr., 1955, Monazite placers of the Broad River and Thicketty Creek, Cherokee County, South Carolina: U.S. Atomic Energy Commission Report RME-3126, 30 p.

Hansen, L. A*, and White, A. M., 1954, Monazite placers on South Muddy Creek, McDowell County and Silver Creek, Burke County, North Carolina: U.S. Atomic Energy Commission Report RME-3115, 28 p.

Harrah, H. W., 1967, Rare earth concentration at Molybdenium Corporation of America, solvent extraction plant [Mountain Pass, Calif.]: DECO TREFOIL Bulletin M4-B167, p. 9-16.

Hedlund, D. C., and Olson, J. C., 1961, Four environments of thorium-, niobium-, and rare-earth-bearing minerals in the Powderhorn district of southwestern Colorado, in Geological Survey Research 1961: U.S. Geological Survey Professional Paper 424-B, p. B283-B286.

1973, Geologic map of the Carpenter Ridge quadrangle, Gunnison County, Colorado: U.S. Geological Survey Geologic Quadrangle Map GQ-1070, scale 1:24,000.

1975, Geologic map of the Powderhorn quadrangle, Gunnison and Saguache Counties, Colorado: U.S. Geological Survey Geologic Quadrangle Map GQ-1178.

Heinrich, E. W., 1966, The geology of carbonatites: Chicago, Rand McNally and Co., $555 \mathrm{p}$.

Heyl, A. V., Jr., and Brock, M. R., 1961, Structural framework of the Illinois-Kentucky mining district and its relation to mineral deposits, in Geological Survey Research 1961: U.S. Geological Survey Professional Paper 424-D, p. D3-D6.

Heyl, A. V., Jr., Brock, M. R., Jolly, J. L., and Wells, C. E., 1966, Regional structure of the southeast Missouri and Illinois-Kentucky mineral districts: U.S. Geological Survey Bulletin 1202-B, 20 p.

Hunter, J. F., 1925, Pre-Cambrian rocks of Gunnison River, Colorado: U.S. Geological Survey Bulletin 777, 94 p.

Johnson, N. L., 1966, Rare earth concentration at Molybdenurn Corporation of America [Mountain Pass, Calif.]: DECO TREFOIL Bulletin M4-B128, p. 1-8.

Kline, M. H., Griffith, R. F., and Hansen, L. A., 1954, Hollow Creek monazite placer, Aiken County, South Carolina: U.S. Atomic Energy Commission Report RME-3127, $29 \mathrm{p}$.

Kremers, H. E., 1958, Commercial thorium ores: Soc. Mining Engineers of Am. Inst. Mining Engineers preprint 5819 A18, p. 1-14.

Larsen, E. S., 1942, Alkalic rocks of Iron Hill, Gunnison County, Colorado: U.S. Geological Survey Professional Paper 197-A, p. 1-64.

Marshall, M. H., 1956, Part II Southeastern United States, in Eilersten, D. E., and Lamb, F. D., compilers, A comprehensive report of exploration by the Bureau of Mines for thorium and radioactive black mineral deposits: U.S. Atomic Energy Commission Report RME-3140, issued by U.S. Atomic Energy Commission Technical Information Service Extension, Oak Ridge, Tenn., p. 29-46.
Mertie, J. B., Jr., 1953, Monazite deposits of the southeastern Atlantic States: U.S. Geological Survey Circular 237, $31 \mathrm{p}$.

1975, Monazite placers in southeastern Atlantic States: U.S. Geological Survey Bulletin 1390, 41 p.

Miller, T. P., and Bunker, C. M, 1976, A reconnaissance study of the uranium and thorium contents of plutonic rocks of the southeastern Seward Peninsula, Alaska: U.S. Geological Survey Journal of Research, v. 4, no. 3, p. $367-377$.

Nash, W. P., 1972, Mineralogy and petrology of the Iron Hill carbonatite complex, Colorado: Geological Society of America Bulletin, v. 83, no. 5, p. 1361-1382.

Olson, J. C., 1975, Geologic map of 'he Rudolph Hill quad. rangle, Gunnison Hinsdale, and Saguache Counties, Colorado: U.S. Geological Survey Geologic Quadrangle Map GQ-1177.

Olson, J. C., and Hedlund, D. C., 1973, Geologic map of the Gateview quadrangle, Gunnison County, Colorado: U.S. Geological Survey Geologic Quadrangle Map GQ-1071, scale 1:24,000.

Olson, J. C., Marvin, R. F., Parker, R. L., and Mehnert, H. H., 1977, Age and tectonic setting of Lower Paleozoic alkalic and mafic rocks, carbonatites, and thorium veins in south-central Colorado: U.S. Geological Survey Journal of Research, v. 5 no. 6 , p. 673-687.

Olson, J. C., and Overstreet, W. C., 1964, Geologic distribution and resources of thorium: U.S. Geological Survey Bulletin 1204, $61 \mathrm{p}$.

Olson, J. C., Shawe, D. R., Pray, L. C., and Sharp, W. N., 1954, Rare-arth mineral deposits of the Mountain Pass district, San Bernardino County, California: U.S. Geological Survey Professional Paper 261, 75 p.

Olson, J. C., and Wallace, S. R., 1956, Thorium and rareearth minerals in Powderhorn district, Gunnison County, Colorado: U.S. Geological Survey Bulletin 1027-0, p. 693-723.

Organization for Economic Cooperation and Development, European Nuclear Agency, 1965, World uranium and thorium resources: Paris Organization for Economic Cooperation and Development, European Nuclear Energy Agency, 22 p.

Overstreet, W. C., 1967, The geologic occurrence of monazite: U.S. Geological Survey Professional Paper 530, 327 p.

Overstreet, W. C., Theobald, P. K., Jr., and Whitlow, J. W., 1959. Thorium and uranium resources in monazite placers of the western Piedmont, North and South Carolina: Mining Engineering, v. 11, no. 7, p. 709-714.

Overstreet, W. C., White, A. M., Whitlow, J. W., Theobald, P. K., Jr., Caldwell, D. W., and Cuppels, N. P., 1968, Fluvial monazite deposits in the southeastern United States, with a section on Mineral analyses by Jerome Stone: U.S. Geological Survey Professional Paper 568, $85 \mathrm{p}$.

Parker, R. L., and Sharp, W. N., 1970, Mafic-ultramafic igneous rocks and associated carbonatites of the Gem Park Complex, Custer and Fremont Counties, Colorado: U.S. Geological Survey Professional Paper 649, 24 p. 
Pitkin, J. A., 1974, Preliminary thorium daughter contour map and profiles of the Hicks Dome area, Hardin County, Illinois: U.S. Geological Survey Open-File Report 74-157. 9 p.

Rose, C. K., and Shannon, S. S., Jr., 1960, Cebolla Creek titaniferous iron deposits, Gunnison County, Colorado: U.S. Bureau of Mines Report of Investigations 5679 , $30 \mathrm{p}$.

Scott, G. R., and Taylor, R. B., 1975, Post-Paleocene Tertiary rocks and Quaternary volcanic ash of the Wet Mountain Valley, Colorado: U.S. Geological Survey Professional Paper 868, $15 \mathrm{p}$.

Scott, G. R., Taylor, R. B., Epis, R. C., and Wobus, R. A., 1976, Geologic map of the Pueblo $1^{\circ} \times 2^{\circ}$ quadrangle, south central Colorado: U.S. Geological Survey Map Miscellaneous Field Studies Map MF-775, scale $1: 187,500$.

Sharp, B. J., and Hetland, D. L., 1968, Thorium and rare earth resources of the Lemhi Pass area, Idaho and Montana: U.S. Atomic Energy Commission, Resource Investigation Division Report AEC-RID-3, $13 \mathrm{p}$.

Shawe, D. R., 1953, Thorium resources of the Mountain Pass district, San Bernardino Counly, California: U.S. Geological Survey Trace Elements Investigations Report $251,73 \mathrm{p}$.

Shawe, D. R., and Parker, R. L., 1967, Mafic-ultramafic layered intrusion at Iron Mountain, Fremont County, Colorado: U.S. Geological Survey Bulletin 1251-A, p. A1-A28.

Sondermayer, R. V., 1975, Thorium: U.S. Bureau of Mines Commodity Data Summaries, 1975, p. 172-173.

Staatz, M. H., 1972a, Thorium-rich veins of Hall Mountain in northernmost Idaho: Economic Geology, v. 67, no. 2, p. 240-248.

$1972 \mathrm{~b}$, Geology and description of the thorium-bearing veins, Lemhi Pass quadrangle, Idaho and Montana: U.S. Geological Survey Bulletin 1351, 94 p.

1974, Thorium veins in the United States: Fconomic Geology, v. 69, no. 4, p. 494-507. 1979, Geology and mineral resources of the Lemhi
Pass thorium district, Idaho and Montana, with a section on Description of selected thorium veins by M. H. Staatz, B. J., Sharp, and D. L. Hetland: U.S. Geological Survey Professional Paper. 1049-A In press.

Staatz, M. H., Bunker, C. M., and Bush, C. A., 1972, Thorium distribution in a granite stock near Bull Canyon, Lemhi County, Idaho: U.S. Geological Survey Professional Paper 800-B, p. B51-B56.

Staatz, M. H., Shaw, V. E., and Wahlberg, J. S., 1972, Occurrence and distribution of rare earths in the Lemhi Pass thorium veins, Idaho and Montana: Economic Geology, v. 67 , no. 1 , p. $72-82$.

1974, Distribution and occurrence of rare earths in the thorium veins on Hall Mountain, Idaho: U.S. Geological Survey Journal of Research, v. 2, no. 6, p. 677-683.

Temple, A. K., and Grogan, R. M., 1965, Carbonatite and related alkalic rocks at Powderhorn, Colorado: Economic Geology, v. 60, no. 4, p. 672-692.

Theobald, P. K., Jr., 1962, Description, composition, and tenor of unconsolidated sediments in monazite-bearing tributaries to the Broad River in western Piedmont of South Carolina and North Carolina: U.S. Geological Survey Open-file report 654, $18 \mathrm{p}$.

Trace, R. D., 1960, Significance of unusual mineral occurrence at Hicks Dome, Hardin County, Illinois: U.S. Geological Survey Professional Paper 400-B, p. B63-B64.

Wedepohl, K. E., 1971, Geochemistry: New York, Holt, Rinehart, and Winston, $231 \mathrm{p}$.

White, A. M., 1962, Description, composition, and tenor of unconsolidated sediments in monazite-bearing tributaries to the Catawba River in the western Piedmont of North Carolina: U.S. Geological Survey Open-file report, $17 \mathrm{p}$.

Williams, Lloyd, 1967, Heavy minerals in South Carolina: South Carolina State Development Board, Division of Geology, Bulletin 35, 35 p.

Zartman, R. E., Brock, M. R., Heyl, A. V., and Thomas, H. H., 1967, K-Ar and $\mathrm{Rb}-\mathrm{Sr}$ ages of some alkalic intrusive rocks from central and eastern United States: American Journal of Science, v. 265, no. 10, p. 848-870. 